\title{
ALCANCES Y PERSPECTIVAS EN TORNO A LA MIGRACIÓN DE MUJERES A TRAVÉS DEL TESTIMONIO DE MUJERES ECUATORIANAS EN CHILE
}

Lucía Valdivieso. Magíster en Antropología y Desarrollo. Universidad de Chile

\section{INTRODUCCION}

En los últimos años, los estudios sobre géne ro han tomado un lugar relevante en la investigación social. En ellos se ha buscado hacer "visible" el papel de la mujer en la sociedad, ya sea partir de su participación económica y política en los mercados de trabajo formal e informal como en su rol tradicional al interior de la familia y en diversos movimientos sociales.

El Presente estudio contiene los resultados de la investigación realizada en torno a migración femenina en Chile a través de los testimonios de un grupo de ecuatorianas venidas a Chile en los últimos cinco años. A partir de las distintas hablas se irán articulando las respuestas en torno a ¿Cómo viven las mujeres que migran a Chile dicho proceso desde una dimensión social, cultural y económica? ¿Qué las empuja a emprender este viaje? Cuál es el papel de la familia en el proceso migratorio antes y después? ¿En qué se apoyan para lograr insertarse en esta sociedad? ¿Qué mecanismos y etapas viven en el largo camino de la adaptación? ¿Cómo han ido reconstruyendo su cotidianidad? Y, finalmente ¿Qué efectos provoca esta experiencia en su identidad cutural y cultural?

Al recuperar y destacar aquí una imagen activa de mujer en los procesos migratorios sobre la base de una perspectiva de género que rescata su rol fundamental en los procesos de adaptación cultural, como también un enfoque más dinámico de lo que sucede al interior de del grupo familiar, como estructura de relación entre géneros y entre generaciones, con conflictos, cuestionamientos de autoridad, reformulaciones, juegos de poder. Etc.

El desarrollo de una reflexión más profunda sobre género, familia y migración, se resiente tanto por la falta de análisis de datos agregados al nivel nacional como por la ausencia de 
estudios puntuales. Más aún estos estudios puntuales son de fundamental importancia para la detección del modo como las relaciones de género y las diferencias en los sistemas de género interfieren en los mecanismos migratorios y qué alteraciones ocurren en estas relaciones en los países receptores.

Quienes tienen a su cargo el estudio de las migraciones internacionales, establecen que en la actualidad hay alrededor de 125 millones de personas viviendo fuera de sus países de origen, por diversos motivos, entre estos motivos destacan los referidos a necesidades económicas, profesionales o políticas. Tal es el caso en Chile que ha dado cobijo a una diversidad de ellas como son mujeres técnico -profesionales, estudiantes, dueñas de casa, mujeres trabajando en el área de servicios entre los que destacan las asesoras del hogar, mujeres con el conocimiento de algún oficio que se desempeñan en las más diversas actividades.

En el presente trabajo se analiza un grupo de mujeres inmigrantes ecuatorianas de entre 20 a 40 años de distintas condiciones socio-económicas, educacionales y estructura familiar enfrentadas al proceso migratorio y al desafío de conseguir mejores y mayores oportunidades para ellas y sus familias. Sin embargo, la migración ecuatoriana no es el objeto de estudio en sí mismo sino es un recurso para aproximarse y redescubrir el fenómeno de la migración a partir de la mirada de género y del análisis de categorías socioantropológicas instaladas en un enfoque muy micro hacia la exploración de las subjetividades e intersubjetividades presentes en dicha problemática.

En consonancia con lo anterior, los antecedentes empíricos son presentados en la primera parte de este estudio, en donde se hace una revisión de tendencias a partir de la segunda mitad del S. XX respecto de los patrones de movilidad internacional en los países de Latinoamérica y el Caribe; se analiza el comportamiento socio-demográfico de los actuales movimientos migratorios en países de la región Andina y Chile como país receptor de migración y la presentación de datos estadísticos sobre migración ecuatoriana en los últimos años. 
Los antecedentes teóricos son el segundo abordaje sobre el tema, a partir de los cuales se buscará explorar, interpretar y analizar la migración femenina. Tres son los ejes teóricos propuestos. El primero relacionado con la definición de "cultura" a partir de categorías utilizadas en la Antropología cultural junto a la noción de "transformación socio-cultural" a partir de algunas nociones trabajadas por G. Germani(1971) y Munizaga,(1978) identificando tiempos, mecanismos de transición, situaciones aculturativas y etapas en torno a la migración.

Un segundo eje aborda varias interrogantes en torno al tema de la identidad cultural y social a partir de la mirada crítica de Michel De Certeau (1990), Said(1990) y Chambers(1994) y a modo de respuesta las nociones utilizadas por Roger Bastide(1973) en relación a la aculturación material y formal.

Un tercer eje analítico se estructura a partir de la noción "unidad doméstica” propuesto por Gregorio Gil (1999) y se analiza las relaciones de género en relación con la migración explicando de manera muy clara cómo seguirá en aumento este fenómeno.

Luego la presentación de la estrategia metodológica que en relación con los objetivos del estudio y dada la naturaleza del fenómeno, se consideró pertinente un diseño de tipo cualitativo bajo una perspectiva interpretativa. Dicha estrategia permitió el descubrimiento, la categorización, la profundización y análisis de las distintas dimensiones tanto de los aspectos subjetivos e intersubjetivos presentes en la migración desde la opinión y percepción de sus actores situaciones y contextos.

La segunda parte de la investigación presenta los resultados organizados de acuerdo a las interrogantes que dieron origen al estudio y su consiguiente análisis; finalmente las conclusiones generales que integran los apartados señalados y sus anexos correspondientes. 


\section{FUNDAMENTACION DEL ESTUDIO}

Aunque el fenómeno de la migración no es algo nuevo en la historia de la humanidad, sí lo es en la actualidad por sus muchas dimensiones y naturaleza; pues a diferencia de una migración expansiva y colonizadora pasada, hoy éste a nivel mundial está pincelado por una complejidad de situaciones en la que destaca la cada vez frecuente presencia de mujeres, dando como resultado un fenómeno que se ha denominado "feminización de la migración"

Mujeres agobiadas por las crisis económicas, sociales y políticas experimentadas en la falta de empleo, alternativas de educación y condiciones de inseguridad social etc., sumadas a factores como la transnacionalización de los proyectos económicos, el progreso tecnológico en los medios de comunicación y transporte en un contexto globalizador, son catalizadores de movilidad y desarraigo.

El tema de la feminización de las migraciones, es un enfoque muy actual dentro de los estudios sobre migración internacional. En ellos se reflejaría un nuevo modo de distribución y utilización creciente de la fuerza de trabajo femenina, en particular, de las mujeres del tercer mundo. Su sentido último, estaría dado por la globalización de la economía. Correspondiendo este análisis a una dimensión político-económica.

Sin embargo el tema no se agota aquí puesto que la migración femenina por sí sola reviste de gran complejidad, razón por la cual se hace necesario integrar y caracterizar aspectos relacionados con una dimensión sociocultural al fenómeno de la migración femenina con algunos conceptos heredados de la Antropología y la Sociología como son la asimilación cultural, la identidad de género, la aculturación etc. De esta manera los contenidos presentes en la migración muestran a este fenómeno socio-cultural como algo muy dinámico. 
En el presente trabajo se analiza un grupo de mujeres inmigrantes ecuatorianas de entre 20 a 40 años de distintas condiciones socio-económicas, educacionales y estructura familiar enfrentadas al proceso migratorio y al desafío de conseguir mejores y mayores oportunidades para ellas y sus familias. Sin embargo, la migración ecuatoriana no es el objeto de estudio en sí mismo sino es un recurso para aproximarse al fenómeno de la migración como tal a partir de la mirada de género.

En consecuencia, la presente investigación es un registro exploratorio que intenta dar cuenta de varias interrogantes, que se describen acontinuación: ¿Cómo han vivido las mujeres que han migrado a Chile el proceso desde el punto de vista social, cultural y económico? ¿Cuáles son sus motivaciones? Cuál es el papel de la familia en el proceso migratorio ¿Cómo operan en el proceso las distintas redes sociales? ¿Qué mecanismos usan para su adaptación?¿Cómo reconstruyen su vida cotidiana? ¿Qué efectos provoca esta experiencia en su expectativa de vida y en sus entornos sociales? Y finalmente como uno de los aspectos claves que guían este estudio ¿Cómo reconstruyen y experimentan estas mujeres su identidad social y cultural?

El supuesto que guío el estudio fue sostener que las mujeres que han debido migrar no sólo han debido atravesar un cambio de escenario geográfico, social y cultural sino que e supone además, un cambio en el mundo de vida, en el estilo de vida, en las expectativas de ésta, en una nueva identidad social y cultural. Siendo este proceso no lineal, homogéneo e idéntico; los aspectos y situaciones vividos en la experiencia son construidos indistintamente, por lo tanto, un individuo, varios individuos, distintas voces y situaciones no son generalizables, sino elementos de mayor profundización del fenómeno.

De esta manera resultaba particularmente interesante explorar dicho proceso en la percepción de mujeres inmigrantes a partir de la recreación de escenarios, historias y situaciones individuales que dieran cuenta de la complejidad del fenómeno de inserción social y cultural, contrastando la información con el fin de reconstruir dicho proceso en sus distintas etapas, buscando en la memoria social y cultural de cada una de ellas a través de la operacionalización de conceptos provenientes de la Antropología. 
Para dar cuenta de tal objetivo en este estudio socio-cultural, se buscó reconstruir las distintas etapas en el tránsito de mujeres ecuatorianas hacia Chile, identificando las redes sociales existentes en cada una de ellas; además de caracterizar las distintas estrategias adaptativas y de integración a la sociedad chilena identificando para ello ciertos eventos y situaciones que fortalecían el proceso $\mathrm{y}$, finalmente, un análisis sobre los efectos del proceso migratorio en la configuración de la identidad cultural y social de la mujer migrante.

La importancia de este tipo de estudio es proporcionar información empírica y de análisis respecto a procesos migratorios internacionales en Chile, a instituciones preocupadas por ello en relación al modo como las relaciones de género y las diferencias en los sistemas de género interfieren en los mecanismos migratorios, y qué alteraciones ocurren en estas relaciones en los países emisores y receptores. Así como también, entregar insumos de primera mano que permitan _eventualmente_corregir aspectos discriminatorios presentes en las políticas migratorias y sensibilizar a la opinión pública respecto del tema

Dependiendo de variables demográficas tales como la edad, sexo, país de origen, nivel de escolaridad, estructura familiar el cuadro de la migración en Chile se va pincelando de distintas características. Las últimas estadísticas obtenidas por la Oficina Nacional de Inmigración estiman un aumento de mujeres inmigrantes ecuatorianas que han obtenido visa en el último año, de 248 en el año 96 a 1036 en el 2000. cifra que sumados años anteriores corresponde a un $49.8 \%$ dentro de un total de 6448 ecuatorianos legales en Chile entre 1996 y 21 2000. Particularidad que reviste de elementos de análisis muy específicos ya que muchas de ellas han debido dejar atrás sus hogares, su entorno y están enfrentadas al desafío de conseguir mayores y mejores condiciones de vida, teniendo para ello que adaptarse a un medio natural, social, económico y cultural distinto. Por lo tanto resulta fundamental el análisis y la caracterización de la migración femenina a través del proceso de inserción de mujeres ecuatorianas en Chile en lo económico-laboral, lo social y cultural que de cuenta de la dinámica respecto al tema de la identidad de género. 
Revista Mad. No.4. Mayo 2001. Departamento de Antropología. Universidad de Chile http://rehue.csociales.uchile.cl/publicaciones/mad/04/paper04.htm

\section{PRIMERA PARTE}




\section{3.- ANTECEDENTES DEL ESTUDIO}

\subsection{Migración y Globalización}

La migración es un fenómeno histórico permanente que se relaciona con contextos de orden estructural, sean éstos económicos, políticos o sociales en distintos países y épocas. Dicho fenómeno se ha visto agudizado en la actualidad en diferentes escenarios geográficos, producto de las condiciones imperantes en el capitalismo tardío, de unas regiones con respecto a otras y que se relacionan con las condiciones de vida en las que vive gran parte de la población del tercer mundo.

Específicamente, el proceso de modernización como encrucijada de la modernidad en países de Latinoamérica ha acelerado las brechas históricas y deprimido los indicadores de desarrollo como son el acceso a la educación, oportunidades laborales y salariales. Brunner (1994), habla de distintas realidades de modernidad que conviven en América latina, con condiciones peculiares de existencia en las distintas naciones que componen la región, enfrentadas a procesos de modernización y de consumo.

El alto nivel de migración en Latinoamérica va a estar directamente relacionado con estos modos de aceleración en los procesos de modernización en cada uno de estos países, y factores como las disparidades correspondientes entre países en la oferta de empleo y en los salarios, los términos cambiarios desiguales entre monedas, además el complicado acceso a bienes y servicios, se combinaron con las adversas condiciones de inestabilidad e intolerancia política y de precariedad social originando numerosos flujos de desplazados hacia otras regiones.

\subsection{Grandes Patrones de la Movilidad Regional}

La ausencia de información apropiada, relevante y oportuna inhibe el examen riguroso de los comportamientos y tendencias en el tema de la migración internacional. Lo cual se 
origina en las limitaciones de las fuentes de información de que se dispone, ya que si bien son datos de entrada y salida, éstos son muy carentes ya que contienen solamente la cifra indeterminada de turistas, entre los cuales se hace imposible determinar y cuantificar el porcentaje de los que se quedan; además de lo anómalos que resultan ser los pasaportes, visados o permisos para dar cuenta del mismo fenómeno.

Buena parte de las políticas migratorias, su análisis y el adecuado manejo de la misma, se produce sobre la base de manipulaciones con los pocos datos disponibles. Se percibe como algo que aumenta en proporciones pero se desconoce la cantidad exacta y la peculiaridad que envuelve el fenómeno.

La numerosa información Centro Latinoamericano de Demografía a través de su proyecto de Investigación sobre Migración Latinoaméricana (IMILA:1988) en relación al estudio de la migración internacional, ha hecho posible no sólo examinar la magnitud de las diversas corrientes tanto de países de origen como de destino, sino también evaluar condiciones comunes y diferentes en cuanto a aspectos socioeconómicos, junto a la detección de los períodos de llegada; material que ha servido para indagar acerca de los posibles factores determinantes y las consecuencias de la migración, como serían las características educativas, conyugales y situación laboral de estas personas y de sus países.

Una revisión de tendencias registradas a lo largo de la segunda mitad del s. XX (Pellegrino 1989:93), permite identificar tres grandes patrones migratorios en América Latina y El Caribe:

- La migración de ultramar, la migración dentro de la región y la emigración extraregional

El patrón de estos movimientos son de distintas clases; entre ellos, los fronterizos, los de búsqueda de refugio y asilo, los de retorno a los países de origen, los de mano de obra, los de profesionales calificados, etc; difícilmente identificables con la información disponible. 


\section{a) La Inmigración de Ultramar}

Fue intensa, aunque fluctuante en el período entre finales del s. XIX y XX, dicha corriente de inmigración tuvieron como destino preferente aquellos países que exhibían condiciones favorables para la inserción de personas provenientes del Sur de Europa.

\section{b) El Patrón Migratorio dentro de la Región}

América Latina se distingue por desplazamientos humanos a través de las fronteras de sus países, pues sus raíces estructurales se vinculan con la histórica heterogeneidad económica y social de los territorios de la región. Las corrientes se han dirigido de preferencia hacia países que disponen de estructuras productivas más favorables para la generación de empleos y que detentan mayores grados de equidad social.

Estos desplazamientos se facilitaron por la vecindad geográfica, la proximidad cultural y un conjunto de vinculaciones históricas. Además, la evolución del patrón ha sido sensible a las coyunturas de expansión o retracción económica y a las contingencias políticas experimentadas por los países. El panorama observado alrededor de 1990 es el resultado neto de una multiplicidad de movimientos que tuvieron lugar durante el decenio previo y que comprenden episodios de emigración y retorno a los países de origen.

\section{c) El Patrón migratorio extraregional}

La emigración hacia el exterior comenzó a adquirir un papel predominante, especialmente hacia los Estados Unidos, Canadá, y en menor medida hacia Europa, Oceanía y Asia. Los antecedentes disponibles evidencian un gradual fortalecimiento del fenómeno de migración Sur - norte, que conlleva repercusiones para la región: pérdida de recursos humanos calificados, dificultades para el ingreso o permanencia de migrantes en países de destino, envío de remesas a los países de origen y formación de comunidades binacionales de migrantes. 


\subsubsection{Características de la Migración Actual en la Región}

En muchos países la emigración contribuyó a aliviar el impacto de las tensiones entre las tendencias demográficas y la generación de empleo, de las originadas en conflictos sociopolíticos, étnicos o religiosos o de las asociadas a formas de degradación ambiental. A escala individual, la emigración es una opción para buscar, fuera de los países de nacimiento, oportunidades laborales o sociales y como correlato para las comunidades de origen, una fuente de divisas y la posibilidad de vincularse con la innovación tecnológica pero puede ser también causa de inestabilidad social y sicológica, frustración y trato discriminatorio por el surgimiento de percepciones negativas frente a los costos de la utilización que hacen los inmigrantes de servicios sociales subsidiados (Salud, educación, seguridad social).

Si bien los efectos futuros de las reformas económicas liberalizadoras, incluida la integración de los mercados, intensificarán la comunicación y los intercambios; es difícil predecir lo que sucederá. Es probable que mientras se mantengan las grandes desigualdades en el grado de desarrollo relativo entre los países, la migración tenderá a crecer con el estímulo de las redes sociales establecidas por los migrantes que ayudarán a materializar e incentivar las expectativas de movilidad.

\section{a) Patrón migratorio en la región Andina}

La tendencia predominante en los países andinos ha sido el mantenimiento de políticas de inmigración selectiva, altamente restrictivas, que buscan establecer un control sobre el ingreso de población extranjera, propiciando al mismo tiempo la captación de recursos humanos calificados en aquellas áreas donde la oferta nacional se considera insuficiente. Estas políticas están presentes en todos los países de la región andina, pero en la práctica no ejercen ningún efecto sobre los ingresos irregulares de población migrante, pues existen mecanismos que permiten evadir con frecuencia las restricciones impuestas por las políticas estatales y los organismos de migración. 
De acuerdo con la Organización Internacional para las Migraciones (OIM), las principales corrientes migratorias internacionales identificables en la región andina, son:

- Migraciones laborales fronterizas: Estos movimientos están presentes en casi todas las zonas fronterizas de los países y representan la mayor proporción de las migraciones que se producen en el área andina.

- Migraciones de retorno: Movimientos de población exiliada que ha regresado a sus países de origen

- Movimientos de desplazados y refugiados: En los últimos años el repunte de acciones guerrilleras o terroristas ha dado lugar a desplazamientos de este tipo en población colombiana y peruana.

- Migración selectiva: Referida a la migración de profesionales y técnicos, repercutiendo en la pérdida de recursos humanos calificados.

Si se atiende a la definición propuesta por Singer sobre migración, como "Un proceso social, cuya unidad actuando no es tan solo el individuo, sino un grupo humano y cultural"(1972;175 ).Se puede establecer que las razones que motivan a las mujeres para migrar se relacionan con un sinnúmero de situaciones en el proceso. La información da cuenta que la mayoría de las migraciones femeninas en los últimos veinte años corresponden a las siguientes categorías: la Búsqueda de trabajo, el logro de mayores perspectivas educacionales o el mejoramiento de las condiciones de vida familiares con el desplazamiento obligatorio del núcleo familiar.

En América Latina, dice Browning “Casi sin excepción se observa que hay más mujeres que hombres en las corrientes migratorias internas y externas. La explicación hay que buscarla en factores culturales, oportunidades económicas disponibles y el grado de desempleo por sexo" (1987: 41). 
En un estudio realizado por Eisentadt, respecto de las razones por las cuales migra la gente, se desprende que existirían diferentes esferas de vida respecto a los factores psicosociales o sociológicos para migrar, así: El mantenimiento de cierto grado de existencia física b) el logro de objetivos económicos y materiales c) la necesidad de una identificación con la sociedad y d) la realización propia de la persona. Aspectos que después han sido integrados a otros como por ejemplo: el carácter obligatorio o no, la satisfacción de la vida en el lugar de residencia anterior, la comunicación entre áreas de origen y destino, los obstáculos y la toma de la decisión como factores que son la antesala del fenómeno de la migración. De tal manera que existiría una clara vinculación entre la motivación y el ciclo vital del migrante. $(1978: 21)$

Respecto del análisis de la composición por edad de la población que se traslada, cabe hacer algunas reflexiones: Dicha población tendría una estructura mucho más joven que la población no migrante, comprendida en edades entre los 10 a 35 años. Se trataría entonces de una migración selectiva por edad, en la que la gran mayoría de las personas podrían ser solteras al llegar a la ciudad de destino; sin embargo, pueden haber varias explicaciones al respecto: que sean solteros, que habiendo estado casados han sido obligados a dejar a sus familias por razones económicas en el lugar de origen, desestructurándose el núcleo familiar o que se trasladen junto a su familia.

La explicación a este fenómeno parece estar relacionado al hecho de que en esta etapa habrían menos compromisos económicos o familiares, existiría una mayor disposición a asumir riesgos, con la consiguiente búsqueda de oportunidades laborales o educacionales y la circunstancia de que en este lapso de tiempo tendrían la posibilidad de conocer a sus futuras parejas o constituir nuevas uniones.

Se podría concluir entonces que dentro de los motivos permanentes que dan origen a la migración figurarían las razones económicas o educacionales y ésta se segmenta en un tramo de edad entre 15 a 35 años. Ahora bien Respecto de las mujeres la mayoría migraría por circunstancias de trabajo, por un mayor ingreso o por causas familiares como el traslado del marido. Sin embargo habría una diferencia entre aquellas que tomaron La 
decisión para migrar por razones económicas, laborales o educacionales que denominaremos independientes y aquellas llamadas dependientes que no lo hicieron directamente.

Un análisis realizado por la Celade (1989) da cuenta que el gran porcentaje de individuos que en su lugar de residencia trabajaron en ocupaciones manuales o en agricultura, se trasladaron en su mayoría por razones económicas.

Otro factor explicativo de la encuesta respecto de las motivaciones sugiere que cuanto más alto sea el estrato social, es más probable que se trate de racionalizar el traslado, evitando admitir razones de carácter económico y declarando por ejemplo la educación de los hijos, las mejores condiciones sociales como factores decisivos. En cuanto a las mujeres las tendencias muestran que la mayoría comprendida entre el tramo de 15-29 años lo hace por razones económicas más que educacionales. Las que han sido dependientes y tienen un grado de escolaridad bajo o medio vienen a trabajar como sirvientas o en ocupaciones no manuales y cuanto más avanzada es la edad es más probable que se vengan como dependientes.

Es muy importante en el análisis la procedencia, (rurales o urbanos), su situación ocupacional anterior y el nivel educacional en el que se encontraban a la hora de partir ya que a la luz de estos tres datos se puede determinar gran parte de la estructura ocupacional de los inmigrantes y sus tramos de edad y sexo.

Bogue, formula la siguiente hipótesis: "El desarrollo de cualquier corriente migratoria pasa por una serie de fases; empieza por una invasión inicial, la que gradualmente madura a una fase de asentamiento, que a su vez resulta en el desarrollo de un grupo o colonia de migrantes en el lugar de destino" (1969;68); situación que estaría estrechamente relacionada a una segmentación por sexo en cada una de estas fases. Llegado a un punto máximo de intensidad en la movilidad entre un punto de origen y uno de destino, el ciclo es visto como una rutina que ha sido institucionalizada; de lo cual se podría concluir que un mayor asentamiento indicaría también menos riesgo y adaptación. Durante la primera fase, los hombres tenderían a superar numéricamente a las mujeres, pero cuando llega la fase de 
rutina, la selectividad por sexo casi desaparecería o favorecería mayormente la presencia de mujeres. La migración inicial, que implica mayor riesgo tendería a ser masculina, mientras que la masividad correspondería a un aumento considerable de mujeres.

Muchos de los aspectos que intervienen en esta problemática son factores de orden políticoeconómico; sin embargo el tema no se agota aquí; razón por la cual se hace necesario integrar elementos teóricos relacionados con una dimensión sociocultural y psicológica al fenómeno de la migración femenina con algunos conceptos como son la asimilación cultural, la identidad de género, la aculturación etc. ya que la migración se describe además como un fenómeno socio-antropológico.

\subsection{2.- Migración en Chile}

En la última década, Chile ha sido espectadora de oleadas migratorias desde diversos puntos geográficos de Latinoamérica y Asia, situación que representa el encuentro de culturas diferentes (interculturalidad) dando lugar a un sinnúmero de respuestas y comportamientos de variado contenido. De acuerdo a fuentes de diversa índole, como el Centro de Información sobre Migración en América Latina establece que "Los inmigrantes empezaron aparecer luego del retorno a la democracia, atraídos por la favorable situación económica que se empieza a desarrollar en el país en los inicios de los años noventa" (CIMAL/OIM. Archivo de recortes/ La tercera/ 108). La mayoría de estas oleadas migratorias de la última década, corresponden a ciudadanos peruanos, bolivianos, cubanos, ecuatorianos y colombianos.

Una agencia extranjera de prensa publicaba en Octubre de 1999 da cuenta de la incidencia que esta teniendo en Chile, la presencia de extranjeros de muchas nacionalidades y variadas actividades o profesiones ya sean médicos, músicos, comerciantes, temporeros, trabajadoras domésticos, etc. La Organización Internacional para las Migraciones ha afirmado que "Gran parte de la población chilena ve el tema de la migración como negativo, argumentando que muchos de ellos están quitando posibilidades laborales, creando incomodidad e inquietud por las condiciones en las que muchos de ellos viven y un 
encubierto racismo" (Centro de información sobre migraciones para América Latina Cimal/OIM, 1999)

Estadísticamente la tasa de inmigrantes extranjeros en Chile es baja (1\% ); sin embargo h tendencia en los últimos años ha ido en aumento, de ellos un gran porcentaje son peruanos (98.000 legales e ilegales) ecuatorianos (6.448 con visa), cubanos (5.389)datos estadísticos que corresponden al año 2000, que han sido recogidos del Ministerio del Interior correspondiendo a un tipo de migración en su mayoría fronteriza (laboral o selectiva) cuya característica principal es la cercanía geográfica, cultural, social, etc. Es importante anotar que en el fenómeno de desplazamiento y tránsito internacional de personas, se está volviendo cada vez más notoria la presencia femenina.

Estas estadísticas revelan que entre la población involucrada en los actuales movimientos inmigratorios hay una marcada presencia de mujeres; dicho indicador está presente especialmente en corrientes migratorias de origen económico laboral. Un $22 \%$ de estas mujeres poseen bajo nivel de escolaridad, un $48 \%$ son de niveles medios y un $30 \%$ son profesionales. La mayor parte son atraídas por la imagen de bonanza económica y han llegado por una suerte de cadena humana donde no se han hecho esperar los "enganchadores" que han visto una oportunidad económica y han creado verdaderos sistemas de tráfico humano.

Un grupo relativamente importante de mujeres inmigrantes lo conforman técnicos y profesionales del ámbito de la salud que junto a otros profesionales han logrado acceder en años recientes a puestos vacantes en el sistema de salud pública debido a la fuga de profesionales chilenos hacia la empresa privada. Seguido de mujeres que han venido a Chile y se desempeñan como asesoras del hogar o servicios varios.

El cuadro que se verá a continuación demuestra en primer lugar el incremento de población femenina desde el año 96 hasta la fecha, aumentando considerablemente en el año 98 que se relaciona con la crisis económica en este país. 


\begin{tabular}{|l|l|l|l|l|l|l|l|l|l|l|}
\hline & 1996 & & 1997 & & 1998 & & 1999 & & 2000 & \\
\hline Ocupac- & hombres & Mujeres & hombres & mujeres & hombre & Mujeres & hombre & Mujeres & hombre & Mujeres \\
\hline Profesió. & $\mathbf{8 8}$ & $\mathbf{5 9}$ & $\mathbf{8 7}$ & $\mathbf{4 3}$ & $\mathbf{2 1 7}$ & $\mathbf{1 1 3}$ & $\mathbf{3 1 5}$ & $\mathbf{2 1 5}$ & $\mathbf{3 2 4}$ & $\mathbf{3 0 6}$ \\
\hline técnico & $\mathbf{2 4}$ & $\mathbf{3 2}$ & $\mathbf{2 4}$ & $\mathbf{3 0}$ & $\mathbf{6 4}$ & $\mathbf{9 7}$ & $\mathbf{3 5}$ & $\mathbf{9 7}$ & $\mathbf{5 0}$ & $\mathbf{1 1 2}$ \\
\hline Estudia- & $\mathbf{9 5}$ & $\mathbf{5 1}$ & $\mathbf{1 0 5}$ & $\mathbf{6 5}$ & $\mathbf{1 9 2}$ & $\mathbf{1 5 4}$ & $\mathbf{1 9 8}$ & $\mathbf{1 6 8}$ & $\mathbf{1 7 0}$ & $\mathbf{2 0 7}$ \\
\hline Oficios & $\mathbf{4}$ & $\mathbf{2}$ & $\mathbf{1 3}$ & $\mathbf{7}$ & $\mathbf{2 2 0}$ & $\mathbf{4 9}$ & $\mathbf{9 3}$ & $\mathbf{3 3}$ & $\mathbf{7 8}$ & $\mathbf{4 4}$ \\
\hline Servicio & $\mathbf{7 0}$ & $\mathbf{7 2}$ & $\mathbf{3 5}$ & $\mathbf{5 7}$ & $\mathbf{3 0 6}$ & $\mathbf{3 7 3}$ & $\mathbf{1 2 6}$ & $\mathbf{1 6 9}$ & $\mathbf{1 2 5}$ & $\mathbf{1 4 2}$ \\
\hline Menor & $\mathbf{1 1}$ & $\mathbf{9}$ & $\mathbf{1 2}$ & $\mathbf{1 2}$ & $\mathbf{1 6 1}$ & $\mathbf{1 7 2}$ & $\mathbf{4 7}$ & $\mathbf{4 1}$ & $\mathbf{4 0}$ & $\mathbf{4 1}$ \\
\hline $\begin{array}{l}\text { Dueña } \\
\text { casa }\end{array}$ & & $\mathbf{2 2}$ & & $\mathbf{2 2}$ & & $\mathbf{6 1}$ & & $\mathbf{6 3}$ & & $\mathbf{1 3 2}$ \\
\hline totales & $\mathbf{2 9 2}$ & $\mathbf{2 4 7}$ & $\mathbf{2 7 6}$ & $\mathbf{2 3 6}$ & $\mathbf{1 1 6 0}$ & $\mathbf{1 0 1 9}$ & $\mathbf{8 1 4}$ & $\mathbf{7 8 6}$ & $\mathbf{7 8 7}$ & $\mathbf{9 8 4}$ \\
\hline
\end{tabular}

(Fuente: Ministerio del Interior, 2001)

Las categorías más represenativas corresponden a hombres y mujeres profesionalestécnicos que en su mayoría lo componen médicos, dentistas, paramédicos,etc.; Los estudiantes, son numerosos también pero el registro m cuenta con información detallada sobre las caractectrísticas de estos estudiantes ya que no se sabe si han obtenido su visa de estudiantes porque se encuentran realizando estudios universitarios o de post-grado o al momento de conseguir su visa presentaron documentación que los acreditaba como estudiantes y nada más, con lo cual es probable que una buena parte se haya dedicado a alguna actividad remunerada.

\begin{tabular}{|l|l|l|l|}
\hline Año & 1996 & 1998 & $\begin{array}{l}200 \\
0\end{array}$ \\
\hline categorías & mujeres & mujeres & \\
\hline profesionales & $\mathbf{5 9}$ & $\mathbf{1 1 3}$ & $\mathbf{3 0 6}$ \\
\hline técnicos & $\mathbf{3 2}$ & $\mathbf{9 7}$ & $\mathbf{1 1 2}$ \\
\hline oficios & $\mathbf{2}$ & $\mathbf{4 9}$ & $\mathbf{4 4}$ \\
\hline estudiantes & $\mathbf{5 1}$ & $\mathbf{1 5 4}$ & $\mathbf{2 0 7}$ \\
\hline menores & $\mathbf{9}$ & $\mathbf{4 3}$ & $\mathbf{4 1}$ \\
\hline servicios & $\mathbf{7 2}$ & $\mathbf{1 7 5}$ & $\mathbf{1 4 2}$ \\
\hline dueñas casa & $\mathbf{2 2}$ & $\mathbf{6 3}$ & $\mathbf{1 3 2}$ \\
\hline total & $\mathbf{2 4 0}$ & $\mathbf{7 8 6}$ & $\mathbf{9 8 4}$ \\
\hline
\end{tabular}

(Fuente: Ministerio del Interior, 2001)

Llama la atención el aumento de mujeres en estos movimientos migratorios; observándose que la gran mayoría viene buscando mayores oportunidades de trabajo y de estudio que corresponden en su mayoría a profesionales, técnicos y servicios. 
El número de menores hombres o mujeres es relativamente bajo en comparación con los otros datos y estimándose que hombres o mujeres vienen a Chile sin su familia constituida.

\begin{tabular}{|l|l|l|l|}
\hline Visados & 96 & 98 & 2000 \\
\hline categorías & hombres & & \\
\hline profesionales & $\mathbf{3 1 5}$ & $\mathbf{2 1 7}$ & $\mathbf{3 2 4}$ \\
\hline técnicos & $\mathbf{3 5}$ & $\mathbf{6 4}$ & $\mathbf{5 0}$ \\
\hline estudiantes & $\mathbf{1 9 8}$ & $\mathbf{1 9 2}$ & $\mathbf{1 7 0}$ \\
\hline oficios & $\mathbf{9 3}$ & $\mathbf{2 2 0}$ & $\mathbf{7 8}$ \\
\hline servicios & $\mathbf{1 2 6}$ & $\mathbf{3 0 6}$ & $\mathbf{1 2 5}$ \\
\hline menores & $\mathbf{4 7}$ & $\mathbf{2 7}$ & $\mathbf{4 0}$ \\
\hline dueñas casa & & & \\
\hline total & $\mathbf{8 1 4}$ & $\mathbf{1 1 6 0}$ & $\mathbf{7 8 7}$ \\
\hline
\end{tabular}

(Fuente: Ministerio del Interior.2001)

Del cuadro anterior se desprende que la presencia de hombres profesionales es alto y, como ya se mencionó la mayoría se relacionan con el área de la salud. El área de servicios entre los que se destacan toda clase de actividades como garzones, gasfiter, fumigador etc. también se evidencian en gran número y corresponden a personas con un bajo nivel de instrucción o que han aprendido algún oficio.

La edad promedio está en relación con las razones por las cuales se migra; siendo evidente que la gente ecuatoriana que ha migrado en los últimos años es mayoritariamente gente jovén o adultos jóvenes tratándose de una migración de tipo económica en su mayoría. 


\section{OBJETIVOS DE LA INVESTIGACION}

En función de los antecedentes presentados, queda en evidencia que el tema de la migración regional adquiere variadas características especialmente respecto a la creciente presencia de mujeres en estos desplazamientos, esta región se considera como la subregión que está concentrando mayor número de migrantes intraregionales. A pesar de la importancia del tema, los estudios presentados no dan cuenta de la participación de las mujeres en dichos procesos migratorios y como la variable de género y cultura dinamizan el proceso.

No se encontraron estudios que posibiliten la conexión de los planos micro y macro en un modelo integrado con dimensiones socioantropológicas_sin embargo, esto no quiere decir que no se estén realizando alcances importantes en esta materia; por lo que se hace imprescindible la revisión de las políticas migratorias vigentes en la región desde la perspectiva de género, cultura e identidad para evaluar las orientaciones estereotipadas sobre la condición masculina y femenina. Las nuevas" estrategias y mecanismos" de movilidad territorial tienen como antecedentes altos niveles de desplazamiento territorial de hombres y mujeres en condición de clandestinidad, como otros que siguen los mismos patrones tradicionales.

Los estudios sobre la "feminización" de los desplazamientos internacionales ocupan parte sustancial en esta nueva producción, principalmente en los países del llamado Primer Mundo. Por tanto, es preciso adecuar dichos esfuerzos a la realidad existente en la región que de cuenta de alcances generales y de características diferenciadoras de este fenómeno que se relacionan, en primer lugar, con las razones por las cuales se ha migrado y, en segundo lugar con variables socioeconómicas, educacionales, socio-culturales, entre otras.

En este contexto, el problema de la presente investigación corresponde a explorar los testimonios de diversas mujeres que han debido migrar y los aspectos contenidos en el proceso migratorio relacionados con las razones por las cuales se desplaza, las redes sociales que participan en este hecho, la reconstrucción de mapas cotidianos, la asimilación 
e inserción social, laboral y económica, los efectos de esto en términos de identidad y cultura,etc.

El supuesto que ha guiado esta investigación fue sostener que este proceso no es lineal, homogéneo e idéntico. Los aspectos y situaciones vividos en la experiencia son construidos indistintamente, por lo tanto, un individuo, varios individuos, distintas voces y situaciones no son generalizables, sino elementos de mayor profundización del fenómeno; sin embargo, todas bajo el prisma de un enfoque de género.

El conocimiento social y cultural es aprendido biográfica y culturalmente; sin embargo cualquier interacción producida fuera de este contexto, implicaría una ampliación de este. De esta manera el propósito que guía esta investigación es dar cuenta de la migración desde sus actores, a partir del cambio en sus rutinas, tanto en su dimensión simbólica, ideacional y material, descrito en su objetivo general de la siguiente manera:

\section{Objetivo General}

- Analizar y caracterizar la migración femenina a través del proceso de inserción de mujeres ecuatorianas en Chile en lo económico-laboral, lo social y cultural que de manera que nos permita dar cuenta de la dinámica respecto al tema de la identidad de género.

\section{Objetivos Específicos}

- Reconstruir las distintas etapas en el tránsito de mujeres ecuatorianas hacia Chile

- Describir las distintas estrategias de inserción socio-laboral de ecuatorianas en Chile

- Distinguir las redes sociales existentes y los principales mecanismos adaptativos que están presentes en el proceso de inserción y lo fortalecen

- Identificar los eventos socioculturales que revitalizan la inserción cultural

- Analizar los efectos del proceso migratorio en la configuración de la identidad cultural de la mujer migrante 


\section{5.- MARCO CONCEPTUAL}

Como se ha explicado, el foco de esta investigación está dado por el interés de aproximarse al hecho migratorio y la relación de género que interviene en un grupo de mujeres ecuatorianas de distintas realidades socioeconómicas, educacionales y familiares.

La mirada conceptual desde donde se busca explorar, interpretar y analizar el tema planteado para este estudio, está construida a partir de las siguientes entradas o ejes teóricos:

El primero de estos ejes utilizará tres articulaciones: La primera referente a la noción de cambio socio-cultural a partir de categorías trabajadas por W.Goodenough (1975) en el marco de la Antropolgía cultural. Una segunda en la que se destacan algunas especificaciones realizadas por G. Germani (1971) respecto de la inserción cultural identificando tiempos, situaciones y etapas y finalmente una tercera referida a los mecanismos de adaptación en el proceso de inserción de una cultura a otra a partir de los conceptos trabajos por Munizaga en torno a la migración campo-ciudad.

Un segundo eje teórico, abordará el tema de la identidad y asimilación cultural a partir de varias refelexiones realizadas por Said (1990), De Certeau (1988) y Kristeva(1990) que apuntan a una reconceptualización de lo que se denomina cultura a partir del desarraigo, además dl aporte hecho por Bastide (1973) respecto de aculturación material y formal.

Un tercer Eje explicativo utilizará la noción de género dentro del proceso de feminización de la migración, integrando conceptos y categorías en lo micro y en lo macro; cuyos fundamentos validarán la importancia de estudios que aborden el tema de la reproducción, el poder y control social.

A continuación, se describe con mayor profundidad la perspectiva teórica mencionada: 


\section{Migración: Dimensión: Tiempo y espacio}

Los enfoques teóricos sobre migración pueden ser identificados en dos grandes grupos: El primero, aborda las causas y formas territoriales de la migración; por su parte el segundo incluye enfoques que se proponen explicar los efectos de la migración en los diversos ambientes sociales, económicos, políticos, culturales, etc. Es decir, se trata de análisis que buscan dimensionar el impacto de la migración respecto de los lugares de origen, de destino y de los propios migrantes.

La migración como fenómeno social, se define como la variación temporal y espacial de la organización de una sociedad. Según el Centro Latinoamericano de Demografía "Un movimiento migratorio adquiere esta definición en función de los criterios con los cuales se delimita las dimensiones de tiempo y espacio"(CELADE/Programa de Estudios de Género PGE.not95). Los términos movilidad espacial y migración se distinguen de acuerdo al uso que se hace de esta dualidad, por tanto, la migración supone el cruce de una frontera para radicar la residencia, más allá de ella; mientras que la movilidad espacial supone uno o más cruces de fronteras sin que medie un traslado de residencia.

\subsection{Migración y Cambio Socio - Cultural: Algunas categorías para el análisis}

El tránsito entre una forma de vida a otra no solamente refiere un traslado físico o geográfico de gente, sino que representan formas de vida diferentes, cambio en distintas esferas, una habitualización y costumbres que representan sistemas de pensamiento y de acción con algún grado de diferencia.

Tomando el concepto de Goodenough (1975), respecto de lo ético y lo émico dentro del lenguaje y la Cultura, se puede establecer su importancia a la hora de observar el comportamiento de un fenómeno social o cultural cualquiera sea. Así, la descripción es émica, en la medida en que se basa en los elementos que son inherentes al sistema objeto de estudio, y por el contrario, la descripción es ética cuando se basa en elementos 
conceptuales que no son componentes de este sistema, pero que elaboran conceptualmente su interpretación. $(1975 ; 168)$

Qué cosas comunicamos culturalmente? Los individuos forman concepciones gracias a la experiencia con las cosas, aprenden a utilizarlas y aprenden a hacer las cosas igual que Los otros. Lo que se aprende son las percepciones, los conceptos, las recetas y habilidades necesarias (cosas que se necesitan saber con objeto de hacer cosas que cumplan con las normas de los otros). como convergentes y concordantes con las normas que ellos detentan. Goodenough, define a la cultura como todo aquello que se aprende, o aquello que se necesita saber con objeto de cumplir con los demás y en último caso con la cultura de la cual se participa.

Al observar un objeto, vemos que las diferencias culturales no consisten simplemente en las cosas observadas, sino en las normas implícitas de lo que se observa, una vez creadas éstas son ambientales. Lo que los hombres hacen con ellas depende de cómo las conciben, que creen respecto de ellas, como las valoran y cuales son sus principios para valorarlas. $(1975 ; 191)$

Cuando se habla de la forma de vida, se puede estar hablando de las normas para hacer las cosas y los dispositivos físicos, sociales y la organización de las actividades donde la gente aplica esas normas para llevar a cabo unos propósitos. El aprendizaje de estas normas que en definitiva es una forma de vida incluiría: conceptos, creencias, preferencias, principios y normas asociadas con la mente. Para entender estos procesos culturales no es necesario situarse en el nivel más abstracto y a un nivel colectivo sino basta con observar el comportamiento y comprensión del significado de lo que percibimos.

Según este autor, La cultura como un producto del aprendizaje humano comprendería los siguientes aspectos:

- Las Formas (color, sabor, gusto) en que la gente organiza sus experiencias del mundo real como estructuras de mundo fenoménico. 
- Una vez distinguidas las formas, se distinguen también relaciones entre las formas; existiendo relaciones de espacio, de tiempo, semánticas y simbólicas; relaciones de inclusión y de exclusión y relaciones instrumentales. Es decir las creencias y proposiciones mediante los cuales explican los acontecimientos

- Luego éstas dispuestas en jerarquías o sistemas de valores o de sentimientos. Estos otorgan los principios para seleccionar y establecer propósitos en un mundo cambiante.

- Finalmente, todo lo anterior en procesos operativos para tratar a las personas y las cosas materiales.. Son los principios gramaticales de la acción y una serie de recetas para realizar fines concretos.

Por lo tanto, la cultura constaría de normas para decidir lo que es, para decidir lo que puede ser, lo que no se siente, para decidir que hacer y cómo hacerlo. (1975:198)

Cuanto más segrega la gente sus experiencias en dominios independientes, mayor es el número de estrategias para la acción a desarrollar. Cuánto más amplio es el abanico de situaciones a que parece aplicable una estrategia, más fáciles resultan de afrontar los problemas diarios.

Algunas de las creencias se desarrollan en la experiencia diaria, otras son postulados que integran las verdades auto-evidentes y las verdades. Cuando los factores sentimentales comprometen a los hombres con la verdad de las proposiciones concretas nos conducen al reino de los valores que pueden ser muy variados o muy comunes a una comunidad.

Cada uno tiene su propio sistema de sentimientos personales, es decir, aquellas preferencias que guiarían sus acciones si estaría libre de la sujeción social. Cuanto más similares sean las condiciones en que crezcan las personas, es más probable que sean similares sus valores privados aunque difieran en los detalles. La sensación de que otras personas tengan sentimientos y valores privados similares a los nuestros -positiva o negativamente orientados en el mismo sentido- nos procura un sentimiento de que todos somos de la misma clase. Sentimos que nos comprendemos, que existiría un lazo especial entre nosotros. Tal sentimiento es una contribución a la solidaridad social que Durckeim llamo 
solidaridad "mecánica" en contraste con otra que es "orgánica" y se basa en la mutua dependencia para las gratificaciones de los deseos y no en la certeza de compartir intereses y sentimientos comunes.

Los valores que se expresen en un conjunto dado de reglas son los valores operativos de quienes las sostienen y los valores públicos de cualquier grupo social cuyos miembros consideren la observancia de estas reglas como un requisito para pertenecer.

La posesión o algunos derechos y privilegios dependen de la concordancia con alguna clase de calificación. Tales como edad, sexo, función reproductora, temperamento y actitudes intelectuales junto con otras diferenciadas en habilidad, conocimientos experiencia y sabiduría que garantizan la desigualdad en la mutua dependencia y en el poder real para realizar o interferir la gratificación de los deseos de otro. Tales desigualdades tienden a hacerse mayores en sociedades donde la especialización ocupacional está altamente desarrollada y encuentran expresión en las reglas sociales que están influidos por el peso del poder.

La gente desarrolla recetas o fórmulas para muchos propósitos que se repiten, con ello reducen la cantidad de improvisación necesario pero al mismo tiempo añaden aún más restricciones.

Toda receta es la exposición de un conjunto de condiciones que deben cumplirse si se pretende conseguir un objetivo. Hay requisitos materiales y otros de organización y relación. No sólo son recetas para cosas materiales sino que tienen que ver con la gente (convencer, persuadir, presentarse) estas recetas pertenecen al comportamiento: las formas en que debemos vestir, las formas en que debemos aproximarnos a los demás, las cosas que debemos hacer, decirles y no decirles. Algunas recetas han sido pensadas por anticipado y deducidas de las creencias o comprensiones existentes; a otras se llega a través del esfuerzo y del error. 
Si tenemos poco que perder podemos arriesgarnos a experimentar con ella de forma que mejore nuestra comprensión; pero si estamos muy preocupados por el resultado, trataremos de seguir exactamente la receta. De hecho el comportamiento tiende a adquirir una cualidad esclava o compulsiva y en este sentido o volverse ritualizado.

Cuando hablamos de recetas nos referimos a ideas y comprensiones de cómo hacer las cosas y cuando hablamos de rutinas y costumbres nos referimos a su verdadera realización. La gente desarrolla sus propios hábitos de procedimiento y estilo personales de pensar y convierte en rutina la ejecución de la receta. Las repetidas realizaciones por parte de las mismas personas desembocará en un conjunto de mutuas expectativas y de hábitos mutuamente adaptados que pueden estar conformados en gran medida por el estilo individual de uno de ellos. Esto es así en situaciones de aprendizaje.(1975:218)

A diferencia de las rutinas, que nacen de los hábitos en ejecutar recetas concretas, las costumbres tienen que ver con los hábitos de escoger entre las posibles recetas y posibles rutinas desarrolladas. Una costumbre pues es una receta o una rutina para realizar una receta a la que se recurre regularmente permitiéndolo las circunstancias, con preferencia a otras posibles recetas o rutinas. Las costumbres nacen cuando la elección de recetas o rutinas para ocasiones concretas ha sido convertida en rutina.

Es importante señalar que la gente de dos comunidades puede conocer parecidas recetas pero tener distintas costumbres en cuanto a su uso. Ya que las costumbres consisten en recetas y rutinas a las que la gente recurre regularmente para propósitos repetidos, la misma gente se adapta o habitúa a ellas y adquiere habilidad en su realización. De este modo, las costumbres adquieren un valor superior al derivado de su eficacia. La gente se compromete a hacer las cosas a que está acostumbrada y que, por tanto, le legan de forma natural. Este compromiso puede llevarlo a exigir que se utilicen recetas y rutinas concretas como parte de sus normas de conducta. Guando esto ocurre, una costumbre refleja una obligación social y no solamente un hábito. 
Una vez que se ha establecido una costumbre, los requisitos para ponerla en ejecución se convierten en una restricción que afecta la forma en que otras recetas y costumbres pueden adoptarse con facilidad; es decir, sirve para limitar la forma de las otras costumbres y para limitar las recetas alternativas. El compromiso parece ir implicado en el proceso que ordinariamente denominamos institucionalización, pues normalmente con el consiguiente grado de institucionalización como la cosa necesaria y moralmente adecuada a hacer.

El cambio de las circunstancias afecta la posibilidad de disposición de recursos materiales, personales y habilidades y restringe o expande de frma diversa las posibilidades para utilizar determinadas recetas. Las consecuencias pueden ser la ruptura de los programas muy complejamente estructurados. La gente necesita recetas alternativas y programas alternativos con objeto de realizar sus propósitos adaptándose a un mundo inestable.

Finalmente, cada individuo desarrolla a partir de su experiencia su visión personal y subjetiva del mundo y de sus contenidos (tanto lo cognoscitivo como afectivo de sus experiencias); y que Goodenough ha denominado propioespecto. Dentro de él se encuentran las distintas normas para distinguir, valorar, crear y hacer y lo que él atribuye a las demás personas como expectativas u obligaciones. Cuando atribuye a los otros normas, da sentido al comportamiento de ellos y puede predecirlos y por lo tanto él mismo se hace inteligible para ellos y puede influir en su propio comportamiento para realizar muchos de sus propósitos.

Por lo tanto las normas que son de sus padres son de ellos y algunos más pero las normas de los otros quedan en otro tipo de categorías. Cada grupo de categorías tiene normas que le son peculiares a ellos; las normas que una persona atribuye a otras constituye para él la cultura de ese conjunto.

\section{2 Inserción Cultural}

Gino Germani, respecto de la migración internacional establece la posibilidad de una mayor o menor inserción cultural, dependiendo de la posición relativa del lugar de origen 
del migrante y su lugar de destino en cuanto a variables de prestigio y distancia social entre el uno y el otro sitio. Así una mayor integración y valoración cultural del país de origen por parte de los individuos que migran determinará una integración parcial y transitoria y a fomentar una cierta distancia cultural participando tan poco como sea posible y logrando finalmente una mínima asimilación cultural en el país de destino, mientras que cuando la valoración del país de origen es menor, la migración tenderá a ser permanente y la asimilación más fácil. ( 1971: 83)

La inserción cultural será entendida como un proceso de recepción de una cultura hacia otra, por contacto directo. Dicho proceso se establece en distintos tiempos, situaciones y etapas, entre las cuales se pueden mencionar:

- La adaptación: Una modificación paulatina con la cual se adquiere destreza para vivir en un ambiente. En términos antropológicos se refiere a una modificación cultural realizada para acomodarse a un modelo que se estima deseable.

- La necesidad de pertenencia a lo más básico, un contacto primario es una de las características principales en la inserción, en donde los que participan entran en relaciones íntimas y personales tales contactos pueden ser los niños con sus padres, un grupo de juego, los vecinos, amigos, compatriotas e inmigrantes que se convierten en un soporte.

- La comunicación es la responsable de dotar de encuentros y sentidos a través de la posibilidad de poner en común o intercambiar estados subjetivos tales como ideas, sentimientos, creencias, por medio del lenguaje o por representación visual, imitación o sugestión.

- La coadaptación es un proceso conjunto, que hace posible la acción o conducta del grupo de iguales (misma nacionalidad). Los individuos a fin de constituir un grupo funcional de cualquier índole y para llevar una vida en común tienen que coadaptar o coordinarse entre sí frente a un propósito en común, que es la necesidad de sobrevivir y 
adaptarse a través de cierto intercambio de ideas o sentimientos. No todas las formas de co-adapatación social son cooperativas ya que la tolerancia es una forma de adaptación social pero no es cooperación

- El hecho de compartir una misma nacionalidad da lugar a una comunidad que tendría muchas características del país de origen en pequeña escala y con intereses comunes menos amplios y coordinados.

La comunidad disfruta de una autosuficiencia más limitada que la sociedad pero dentro de dichos límites existe una asociación más intima y una simpatía más profunda.

La nacionalidad por lo tanto se transforma en un vínculo entre los migrantes que si bien comparten ciertos rasgos comunes, no es necesaria la uniformidad. Debe existir sí, conformidad o al menos simpatía y cooperación con respecto a ciertas aspectos claves como el vestido, el lenguaje, la religión el adorno, formas de recreo, código moral, la organización familiar, valores éticos y morales . Lo que los identifica es la idea del "nos" (Mercier: 1970; 84)

El proceso de adaptación reviste de variada complejidad debido a factores socioculturales, como son nivel educacional, diferencias de clase que se transforman en características diferenciadoras y salientes de los diversos estratos sociales y profesionales, especialmente aquellos que se refieren a su comportamiento social, costumbres, patrones de consumo, intereses y actitudes.

Dependiendo de las motivaciones para migrar, el proceso se cumple para la persona dotándole de nuevas herramientas; con ello hay un cambio en el patrón cultural que se evidencia en un ajuste personal, condición, estado por el cual una persona se encuentra en situación de consonancia con una relación social dada en los distintos ambientes (laboral social, familiar, recreativo). 


\section{$\underline{\text { 5.2.1Mecanismos de adaptación }}$}

La situación de vida del inmigrante sea este forzado o voluntario se traduce en "un esfuerzo dramático de reducción de complejidad ya que una vez salido de su marco de referencia se enfrenta a una ruptura y a un desafío por alcanzar sentido y pertenencia. La reducción de complejidad entendida como un proceso humano que ayuda a descifrar situaciones, pero que en el caso particular del inmigrante adquiere variadas dimensiones" (Arnold y Haefner:1988;174)

Las estrategias que se encaminan frente a este propósito van a depender de la carga cultural, ideológica, sicológica que acompañe al individuo. Estas pueden ser la conformación de un nuevo ambiente, la institucionalización de pautas adaptativas, la capacidad para discriminar los distintos planos de la vida diaria y la consecuente elaboración de estrategias para relacionarse con los distintos ambientes. Todos estos aspectos se expresan a través de una paulatina reducción de la complejidad de lo desconocido frente a una única necesidad: la de sobrevivencia.

Arnold y Haefner en su trabajo sobre aculturación en exiliados chilenos, establecen que esta reducción de complejidad es como un continuo embudo; siempre hay nuevas situaciones que enfrentar y nunca se termina de aprender. La conformación subjetiva de un nuevo ambiente está en relación con la situación del individuo o de su grupo al momento de migrar, es decir las expectativas, la capacidad de establecer contactos seguros y el grado de conocimiento del lugar a donde se arribará a lo que denominan "colchón aculturativo".

Para tener una idea es necesario recurrir a una serie de relaciones y conceptos propuestos por Munizaga (1970:13) respecto de la migración rural-urbana. Esta supone que en cada uno de estos medios, son diferentes las categorías mentales usadas por los individuos en su comunicación recíproca. Esta diferencia en el grado de abstracción de ellas constituye una de las fuertes barreras que habría que superar en el tránsito hacia el otro medio. 
Dichas barreras no son siempre fáciles de superar; por lo que, las consecuencias de los cambios sólo pueden ser sondeadas si se conocen de antemano la naturaleza de estas dos formas de vida. Al hablar de tránsito suponemos que existirían algunos efectos como "costos sociales" "desorientación personal" "deterioro moral". En especial se ha dicho que cuando el cambio es demasiado abrupto, mayores son los peligros de que s produzcan estas resultantes negativas.

Supone que si el tránsito entre dos formas de vida a través de la migración se hace complejo es porque en el proceso no existirían demasiados caminos estructurados o ritos de iniciación que ayuden al hombre que migra y le señalen la manera de llegar y de adaptarse a este nuevo ambiente.

\section{Las llamadas "estructuras transicionales"(1970:19) son puentes o mecanismos} intermediarios a través de los cuales es posible atravesar de una forma de vida a otra. En la base de algunas de estas estructuras se produciría la fermentación sociológica, cultural y sicológica de los migrantes.

Lo específico de cada uno de los mecanismos (grupos informales, comunidades, asociaciones) es que los elementos humanos que las activan están incorporados en el medio moderno, industrial, impersonal de la urbe, como también a estructuras relacionales de tipo personal, donde predominan categorías más concretas de pensamiento.

La diferencia étnica y racial de los migrantes contribuyen a "crear" mecanismos transicionales o a reforzar ciertos mecanismos como grupos informales. A veces la diferencia hace que los elementos de la estructura tradicional del grupo minoritario se transforme, se traslade y se reproduzca en algo muy distinto a su de origen.

Sosteniéndose de antemano que los migrantes son gente de un espacio social, geográfico distinto, sea rural o urbano y que éste difiere culturalmente del nuevo medio ya que pertenecen a otra cultura, entonces habrá que revisar aquellos mecanismos que actúan en la migración y aquellos que intervienen en las situaciones de contacto y conflicto cultural. 
El marco teórico utilizado por Munizaga consiste en considerar ambos medios como subsociedades o sub-culturas. Los caminos de acceso y formas de incorporación al medio urbano se encontrarían poco estructuradas. Los problemas de "comunicación" entre las sub -sociedades son los que se pondrían más de relieve en la diferencia y la problemática que surge cuando los individuos migran de una a otra. Ya que mientras en el primer tipo de sociedad predomina un modo de "comunicación" con un marco concreto de pensamiento y un reducido nivel de abstracción basado éste en el uso de categorías particulares y en contactos personales propios de una sociedad homogénea; en las grandes ciudades predomina un tipo de "comunicación" basado en marcos de pensamiento de mayor abstracción apoyados en categorías generales, en contactos más impersonales propios de una sociedad heterogénea.

De manera que en dicho tránsito, el salto abrupto entre dos culturas, la falta de relaciones estables con algún grupo en la fase intermedia, serían las causas de desorientación social y personal que sufren los migrantes. Por lo tanto, el proceso de movilidad se transforma en algo poco estructurado y el estudio de lo que se ha dado en llamar formaciones sociales transicionales_son imperativos en dicho proceso porque se supone que son medios de apoyo que van graduando este cambio.

Los modelos de apoyo pueden surgir como transformaciones de estructuras familiares (parentesco) o ser simplemente creaciones al azar y por la necesidad de tener algún contacto, como es el caso de algunas asociaciones voluntarias o grupos informales surgidos de la interacción con otro medio.

Antropológicamente hablando, el emigrar es incorporarse a otra sociedad, aprender sus usos sus costumbres y comprender sus marcos de pensamiento; Dicho paso no ha sido institucionalizado con algún rito de iniciación, una enseñanza impartida al individuo en un momento crítico de su vida o algún elemento que proporcione e indique al individuo qué hacer, a donde recurrir, cómo enfrentar. Y más aún al encontrarse éste en una fase 
intermedia, se ha desligado paulatinamente de las normas de grupo, de su entorno y no ha llegado aun a integrarse a las del nuevo grupo al cual todavía no pertenece.

Los métodos antropológicos son de vital importancia al momento de descifrar la existencia de patrones de conducta que signifiquen algún tipo de institucionalización o indicios de ella, o que indique ritos de paso para ingresar en otra cultura. La intensidad con que los migrantes puedan percibir los nuevos papeles y "status" como podría ser la imagen de una mujer emancipada, independiente económicamente y con gran libertad sexual y sentimental, complica el tránsito; pues el migrante recién llegado, debe "observar" nuevos "patrones" dentro de ciertos grupos con gran intensidad, la manera cómo los exhiben provocando en ellos un efecto duradero. Es decir, sin ninguna referencia más, éstos se transforman en grupos de referencia o modelos orientadores dentro de esta fase intermedia. Dicha fase a sido denominada por la Antropología clásica "socialización anticipada" como un proceso inestructurado e informal que facilitaría la incorporación de individuos a un grupo de referencia al cual aspiran a pertenecer, enseñándoles gradualmente los nuevos papeles y Status" propios del grupo ajeno.

Es verdad que a través de una constante comunicación entre las redes puede operarse una verdadera "socialización anticipada" para los que aspiran a incorporarse a un nuevo medio pero sólo en el momento de incorporarse a la urbe, es donde se puede ver y actuar en relación con los nuevos sistemas, papeles y status.

Si se conciben estas estructuras transicionales como modelos de apoyo entonces ¿Cuál es la forma en que estas estructuras facilitan el paso entre estos medios? Si se entiende que para superar la barrera cultural los migrantes enfrentan una dificultad en el manejo de categorías concretas de pensamiento a categorías más abstractas, además si esta implica también un obstáculo para pasar bruscamente de una interacción social homogénea a la heterogénea.

La investigación recae en los mecanismos dentro de tales formaciones que permiten algún grado de interacción, gradualmente en aumento, con desconocidos y en un permanente enfrentamiento con el medio en la interpretación de nuevos sistemas de roles. 
intervienen en la adaptación o ajuste de los migrantes como individuos, en la adaptación de los grupos transicionales.

\section{3 Migración: Interculturalidad-Identidad}

La migración junto a la enunciación de fronteras y cruces culturales, es un punto de encuentro de reflexiones contemporáneas, ya que según Edward " la migración supone una forma de ser discontinua, una disputa con el lugar de origen" (Said;1990:357)

Para este autor, el contexto general de la migración se encuentra en la alteridad de un mundo globalizado, otros mundos, otras lenguas e identidades: Ya no está claro el límite de la cultura y la identidad; para este autor la morada en tránsito se construye a través de encuentros, diálogos y disputas con otras historias, otros lugares y otras gentes. Por lo tanto está claro la partida pero no el retorno, ya que exige vivir entre lenguas, historias e identidades que también están sometidas a un constante cambio; así se hace imposible domesticar el circuito, todo es transitorio pero se construye finalmente una experiencia de vida.( 1990:325)

Según Chambers, hablar desde el desarraigo es hablar de una herencia, es referirse a una historia, a una traducción o a la memoria, por lo tanto supone hablar de lo incompleto, de lo que no se puede descifrar completamente, pero supone además renunciar a la transparencia ya que el traducir o referirse a la memoria es utilizar un lenguaje que está atravesado por la pérdida, por otro lugar, otras voces etc. Para él la manera de reconocer y traducir supone estar afectado por una lengua que se ha ido transformando (1994:31)

Llega a la conclusión de que el pensamiento del inmigrante es errático, siempre en tránsito; cuyos cimientos a veces parecerían carecer de base firme. El efecto es la sensación de "morada" o lo que es lo mismo, un hábitat móvil. Se trata pues de un constante viaje y una constante incertidumbre donde se desarman términos de referencia, pues al cruzar fronteras, se rompe con ello límites del pensamiento y de experiencia común. En este sentido, vivir en 
"Otra parte" significa estar con la diferencia a cuestas pero éstas no funcionan necesariamente como barreras sino como signos de complejidad, a lo que se suma la condición de nomadismo del pensamiento moderno.

Finalmente establece que el sentido de la identidad no se resuelve en las categorías del ser, a saber: blanco, inglés y hombre, ya que el lenguaje que nos habita y la historia que hacemos está más allá de la voluntad de este tipo de conceptualizaciones.

En palabras de Kristeva "El drama del extranjero es vivir con una identidad constantemente amenazada que ha sido obligado a salirse de las fuentes de la tradición y además se le exige al extranjero que se sienta cómodo en una interminable discusión entre herencia dispersa y un presente disímil" (1990:152)

De Certeau establece que el inmigrante a su llegada utiliza mapas para encontrar un lugar que no ha visto pero que ha imaginado; sin embargo cuando llega ahí, el lugar, no es el lugar imaginado, es menos verdadero, "lo que perdura es la conversación en la que las diferentes identidades se reconocen, se intercambian y se mezcla, pero no se desvanecen" (1988:18)

Expuesta la problemática del desarraigo y la identidad sobre el pensamiento de autores como Said, De Certeau y Kristeva y la necesidad de resolver algunas de las interrogantes planteadas respecto de la reconstrucción y edificación de la nueva identidad en tránsito, se ha tomado como eje analítico la descripción de la aculturación formal hecha por Bastide.

\section{3.1 ¿Transformación v.s adaptación?}

Durante mucho tiempo y a partir de Durckheim se mantuvo la discusión de que los hechos sociales son estudiados como cosas exteriores o superiores a los individuos. Como consecuencia de esto, la única aculturación que interesaba era la aculturación material. La que se inscribe en los hechos perceptibles es decir, en la difusión de un rasgo cultural o la transformación de un ritual. Más tarde, surgen inquietudes en algunos etnólogos por otro 
tipo de aculturación que no sea la aculturación formal, uniéndose de esta manera ciertos aspectos de la psicología con la Antropología.

Bastide (1973) estudia dicha transformación sobre la experiencia de las sociedades afroamericanas. Define a la aculturación formal como la transformación o metamorfosis de la forma de sentir y aprender propia de esa conciencia. La aculturación formal va mucho más allá que los aspectos que abarcaría la asimilación puesto que es un proceso muy complejo de ajustes y conflictos entre representaciones colectivas, valores, sentimientos de pertenencia. Mientras la asimilación consistiría en la unificación de contenidos presentes en esas conciencias conflictuales, mediante un sagaz equilibrio de los contrarios o la simple adhesión a un sistema único de valores.

Al hablar de la aculturación formal se está hablando de hechos sicológicos vividos y de experiencias que luchan por ocupar un espacio. La reinterpretación que uno hace de la nueva realidad y de la anterior, puede ser de dos maneras: a) como la reinterpretación de la realidad tal en términos de otra realidad o b) como la reinterpretación de una realidad tal en ojos de otra cultura.

La aculturación formal se transforma de esta manera en un concepto neutro y hasta cierto punto operativo, puesto que no contiene la idea de permanencia de una mentalidad, sino que más bien busca entender y relacionar aspectos sociológicos con otros psicológicos individuales; siendo ésta la diferencia más válida entre la aculturación material y la aculturación formal.

Existirían algunos aspectos relacionados con la aculturación formal conectados con el fenómeno del sincretismo y con la aculturación material. Estos son:

- el proceso de cambio de mentalidad

- Las mezclas que puedan producirse

- Las rupturas por las cuales resulta posible que la inteligencia se encuentre ya occidentalizada en tanto la afectividad se conserva en otra realidad cultural o viceversa. 
La pregunta que surge entonces es ¿Cómo se reconocen estos niveles en un individuo si se sabe de antemano que toda forma es inconsciente? Bastide (1973:145) establece la necesidad de dejar atrás el yo de la encuesta y llegar al yo profundo. La aculturación formal es psicológica y por lo tanto en su observación utilizará los métodos de la psicología. Toda forma es un principio de organización y por lo tanto se tienen que reconstruir los procesos de desorganización y de reorganización de antiguas formas de percepción, de memoria, de afectividad y pensamiento. Además, llegar a establecer que hay algunos hechos a los que les sucede hechos análogos al sincretismo, esto quiere decir que el pasaje de una forma a otra no ocurre bruscamente como en línea recta.

Este autor afirma que hacen falta tres generaciones para que la aculturación sea completa y la asimilación haya cambiado poco a poco la percepción. Además de los contenidos, las formas de afectividad y de pensamiento intelectual. Qué ocurre durante la segunda generación? Este autor, Llega a la conclusión que la aculturación formal debe separase de la aculturación material puesto que en su aspecto material una cultura puede haber desaparecido y haber sido digerida por otra cultura dominante pero en cuanto a las estructuras profundas es decir las formas de organización, de memorización, de relación, éstas están presentes por mucho tiempo.

El sincretismo se realiza en la aculturación material según el principio de continuidad porque de dos vertientes y su mezcla se derivan todas las combinaciones posibles al sustituir de forma progresiva una cosa, dotándole de riqueza. En cambio la aculturación formal se realiza mediante la ruptura ya que las organizaciones mentales se presentan como gestalt y no como suma de rasgos. Al estar dentro de un proceso de aprendizaje de un a cultura no se aprende solamente unos términos o leyes de esa cultura sino que se establece una re-elaboración de las categorías destinada a modificar la percepción, la memoria, el proceso de pensar, y a producir la metamorfosis de la sensibilidad. El cambio del contenido de la conciencia determina el cambio de la forma en un juego dialéctico. 
Al igual que la memoria individual, la memoria colectiva también conoce el olvido, y el olvido también está condicionado por la ausencia de un sustrato material que facilite el acoplamiento de los recuerdos. Así, en cierta medida se asiste a la ruptura de un tipo de "cuadro social" de una forma específica de memoria y por consiguiente a la dispersión de la primitiva comunidad en un archipiélago de individuos incomunicados. De tal manera que la memoria vendría a ser algo que se reinterpreta puesto que la memoria de un grupo funciona gracias a la cooperación de todos sus miembros, cada uno de los cuales lleva consigo una determinada categoría de recuerdos que se completan mutuamente y que solo son evocados cuando los individuos vuelven a encontrarse. (1973:178)

\subsection{Identidad cultural/identidad de género}

\section{Género y socialización}

Cómo resuelven las mujeres migrantes su identidad de género y su identidad cultural?

"La individualización, es el resultado del proceso de socialización temprana en la familia, la escuela, etc" (Landi;1981:86) Es en este proceso de identificación y de socialización, en donde está inmerso el conflicto de las desigualdades entre hombres y mujeres. Para adentrarse, en las subjetividades de cada género es necesario llegar hasta la descomposición de los procesos de autoafirmación (dados en el proceso de individualización).

Para la psicología, la identidad en un proceso "localizado en el núcleo del individuo pero también en el núcleo del entorno cultural común en el que el individuo vive... es el resultado de un proceso de múltiples relacione (Erickson;1976:167). Así la identidad de género hace referencia al modo en el cual el ser hombre y ser mujer viene prescrito socialmente por la “combinación status-rol, atribuida a una persona en función de su sexo"(Nieves;1993:79). Es así como se empiezan a considerar las diversas relaciones (como procesos dinámicos) que se desarrollan entre hombres y mujeres, trascendiendo las meramente sexuales hacia un análisis de las relaciones de poder, identificación, control, entre otras. 
Si partimos de la premisa que el "género" es una construcción social por lo tanto hay una relación estrecha entre la cultura que cada hombre y mujer representa y de la cual son parte. Así: "La cultura define sus ideas de hombre y mujer, en base a una ideología de la reproducción, con la mujer con un rol reproductivo y expresivo (maternal, nurturante, de cuidado y de realización a través de los otros); el hombre, con un rol productivo (remunerado) e instrumental (de mediador entre familia y la sociedad, de su representante y protector)" (Raguz;).

Esta idea sobre cómo la sociedad ha identificado a las mujeres y los hombres en sus distintas áreas de acción (privada y pública) y los roles que estos ejercen (produtivo o reproductivo) es en donde surge la necesidad de entender la temática desde lo que se ha denominado "género".

\subsubsection{Género y migración}

Gregorio Gil (1999) distingue dos modelos teóricos que han abordado el tema de las migraciones femeninas como parte de una estructura y ancladas en la motivación definiéndolas al interior de este proceso como sujetos individuales, racionales y sin género.

Propone un tercer modelo que lo denomina "teoría de la articulación con el capitalismo" cuya base explicativa se sustenta en el análisis del núcleo doméstico a partir de dos estructuras fundamentales: la producción y reproducción. (modo capitalista y doméstico) a través del cual un grupo doméstico utiliza la estrategia de la migración internacional como necesaria en su proceso de reproducción y producción.

El grupo doméstico lo define como personas que aseguran su mantenimiento y reproducción por la generación y disposición de un ingreso colectivo. Por lo tanto la emigración puede ser vista como una estrategia de sobrevivencia y reproducción de grupos domésticos frente a la demanda laboral y ocupacional dado en el contexto económico social y político global; a través de mecanismos como el empleo de mano de obra entre una forma de producción a otra. 
Dicha rotación de emigrantes mujeres entre un punto y otro es un mecanismo esencial para el funcionamiento del grupo doméstico hasta llegar a convertirse en algo permanente y necesario.

Sin embargo, las relaciones en el grupo doméstico no son solamente económicas sino ideológicas y simbólicas en relación a lo que desempeña cada uno dentro del grupo, sus aportaciones, beneficios, actividades; por lo tanto se incorpora a este análisis sistemas simbólicos de dominación o ideologías de género que aparecen muy contradictorias solamente con las relaciones materiales.

Para estudiar el grupo doméstico se han de tomar en cuenta dos cosas: lo primero es que los miembros van a ser diferentes en función de su edad, sexo, y lugar de la estructura de parentesco, que a va a determinar una posición distinta en relación con la producción y reproducción. Lo segundo es que dentro del grupo doméstico están incluidas también relaciones de poder unidas con aspectos ideológicos que can a asegurar su permanencia.

\section{$\underline{\text { La red migratoria }}$}

El concepto de red social fue introducido en el tema de las migraciones para estudiar las distintas conexiones relacionadas con la presencia de inmigración latina en los Estados Unidos (Portes \& Rumbaut 1990). Dichas redes son analizadas como micro- estructuras que facilitan dicha movilidad y la convierten en un proceso social autosuficiente. Por lo tanto, definen a la migración laboral como un fenómeno en progresiva construcción de redes llamado también transnacionalismo donde se encadenan las sociedades de origen y las de destino.

Dicha red se refiere a la activación de contactos que forman parte de una red de relaciones preexistentes sean estos de amistad, vecindad, parentesco a lo que algunos autores han denominado también ideología o cultura de la inmigración al referirse a este patrón de creencias y valores sobre la migración (Baéz Evertsz 1992:51). Estas redes proveen de 
información, recursos y todo tipo de bienes y servicios materiales orientados a hacerla posible e implican también un cierto nivel de profesionalización. (George:1990;71) refiriéndose a estas redes establece como claves a los prestamistas, buscones, falsificadores de documentos, organizadores de viajes. Los principales son los buscadores y los prestamistas; el primero que facilita a través de sus contactos las redes y, el segundo que presta el dinero para el viaje.

\section{$\underline{\text { El enfoque de género }}$}

La autora hace la siguiente interrogante ¿Que variables deben ser incorporadas desde un enfoque de género para explicar y comprender los procesos migratorios, sus desencadenantes y sus consecuencias? Estos estudios deberían integrar a la teoría sobre la articulación, una perspectiva antropológica que articule el proceso micro y macro.

Respecto al grupo doméstico definido operacionalmente como el grupo de personas que aseguran su mantenimiento y reproducción por la generación y disposición de una ingreso colectivo (Dinerman 1978) donde se incluyen los siguientes aspectos:

- La división sexual del trabajo que es la que otorga espacios diferentes de desarrollo de las actividades productivas y reproductivas con diferente valor simbólico y en relación a unos mecanismos de control y subordinación del trabajo en función del género.

- Las relaciones de poder dentro del grupo doméstico reflejadas en el acceso a los recursos; mayor o menor poder de decisión; Mayor o menor legitimización de la autoridad y prestigio. Todo esto en función de divisiones de edad, generación y parentesco.

- Las actitudes de los diferentes miembros del grupo doméstico hacia cuestiones como la migración femenina, la separación o abandono del hogar, el empleo de mujeres, el control sexual de éstas y hacia los roles de las mujeres en ge neral.

- La existencia de una ideología respecto a la maternidad/paternidad y el compromiso familiar en el mantenimiento de los grupos domésticos. 
- Una red migratoria se define como un conjunto de relaciones sociales que organizan y dirigen la circulación de trabajo, capital, bienes, servicios, información e ideologías entre comunidades de origen y de destino.

- Las relaciones sociales de parentesco son (filiación, afinidad, compadrazgo, comadrazgo,padrinaje, madrinaje) de vecindad en la comunidad de origen así como las redes de relación dentro de las organizaciones más o menos formales: clubes, grupos comunales, asociaciones, partidos políticos que significan relaciones de autoayuda e intercambio, información y reproducen esquemas de relaciones de género dominantes en las sociedades de origen.

- Las creencias en torno a la emigración y a los roles de la persona emigrante que circulan dentro de las redes sociales así como la existencia de una subcultura de la migración, definida por los comportamientos, normas, lenguaje, ideología, de las personas emigrantes y su configuración en el imaginario colectivo.

- La transcionalización de la red migratoria está dada por la interconexión entre las dos sociedades, lo que puede reproducir o cambiar diferentes aspectos de la relación entre géneros sea en lo económico (envío de dinero y objetos) mercantil(constitución de negocios étnicos) afectivo (llamadas telefónicas, cartas, viajes) sociocultural actividades de ocio, ocupación de espacios públicos o privados 


\section{6.- ESTRATEGIA METODOLOGICA}

En relación con los objetivos del estudio y dada la naturaleza del fenómeno, se consideró pertinente la formulación de un diseño de tipo cualitativo bajo una perspectiva interpretativa. Dicha estrategia permitió el descubrimiento, la categorización, la profundización y análisis de las distintas dimensiones tanto de los aspectos subjetivos e intersubjetivos presentes en la migración desde la opinión y percepción de sus actores situaciones y contextos.

El empleo de metodología cualitativa se refiere en el más amplio sentido, a un tipo de información recogida en la descripción de actividades, formas, comportamientos, pautas, fines, usos etc; lo que facilitó el uso de una técnica y un método a partir de los relatos en las propias palabras de los sujetos, y en la observación que el investigador realizó en distintas situaciones y escenarios.

Uno de los problemas que se plantean respecto de las metodologías cualitativas es el de cómo captar la realidad del fenómeno bajo estudio y cómo darle un sentido convincente. El otorgamiento de sentido hace mención: a) las complejas interpretaciones de los datos efectuadas en el proceso de investigación; b) el carácter conceptualmente denso que debe tener la teoría y c) la complejidad de un examen detallado e intensivo de los datos para determinar la complejidad de las relaciones existentes entre ellos (Strauss, 1989).

La búsqueda de sentido(s) o significado(s) sobre la migración de mujeres no acercó el problema a su comprensión, sino que lo complejizó a partir de sus distintas caras, episodios y situaciones específicas; sosteniendo de antemano que dicho proceso no es lineal, homogéneo e idéntico por lo que los aspectos y situaciones en esta experiencia no son generalizables sino elementos de mayor profundización. Razón por la cual el proceso investigativo se sitúo operacionalmente bajo un contexto de descubrimiento de significados y no desde una perspectiva teórica determinada. 
Haciendo alusión a un enfoque cualitativo interpretativo sobre investigación social, aparece la idea de que el dato es una operación construida en distintas fases a partir de un acercamiento al foco, al contexto y a la periferia del fenómeno o lo que es mejor situar a los datos o textos dentro de contextos; según Gil Flores "Son todas aquellas informaciones relativas a las interacciones de los sujetos entre sí, sus actividades y contextos en los que tienen lugar, la información proporcionada por los sujetos, a iniciativa propia o por requerimiento del investigador, o con el investigador o por los artefactos que construyen y usan (documentos escritos u objetos materiales" (Gil Flores;1994:25)

Para responder a los objetivos planteados se determinó como estrategia, el análisis de los distintos aspectos comprometidos en la experiencia de migrar entre los distintos sujetos que componen la muestra y sus narraciones. Con dicha estrategia metodológica se pretendía la construcción de un "mapa discursivo" sobre dicho tema, en el que fuera posible cruzar información respecto de las distintas percepciones y dimensiones en torno al fenómeno y con ello dar cuenta de los sentidos o significados que la configuran y las razones y acciones que motivan a estas mujeres para seguir en este tránsito. El estudio se focalizó en relatos individuales a través de la técnica de entrevistas en profundidad.

El proceso de investigación se desarrolló en un comportamiento de investigación flexible, en un tipo de investigación sistemática, rigurosa pero no estandarizada, partiendo a lo sumo de algunos "conceptos ordenadores" (Denzin, 1978). Dicho comportamiento está en relación con una dinámica en la que intervienen tanto el investigador como las personas que están inmersas en lo que se está estudiando.

Se enfatiza aquello con el propósito de explicitar el procedimiento de construcción del instrumento de producción de información que fue un puntal en este estudio. Siendo la reconstrucción de significados de los distintos actores involucrados lo que guía la investigación, el investigador se sitúa como facilitador frente a las áreas de interés que en este caso están constituidas por los procesos de que configuran la emigración tales como la antesala del viaje, la inserción, la adaptación, cambio de hábitos, nivel de expectativas, etc., de mujeres ecuatorianos en Chile. 
Para ello se hizo un acercamiento al tema desde las distintas historias y episodios narrados y elaborados por sus protagonistas que luego fueron integrados en una mayor profundización y complejización.

Dichos conceptos se fueron modificando, enriqueciendo, a medida que avanzó el estudio para luego en una segunda etapa reelaborar las preguntas pertinentes, en un ir y venir de los datos a la teoría y viceversa, a lo largo del cual fue cobrando forma este estudio.

\subsection{Universo y muestra del estudio}

El total del universo de estudio correspondió a mujeres ecuatorianas de entre 20 a 40 años de distintas condiciones socio-económicas, educacionales, estado civil etc., que migraron a Chile en los últimos cinco años por distintas razones. De acuerdo a los datos manejados por la Oficina de Inmigración se tiene que desde al año 96 hasta el 2000 llegaron a Chile 3.182 mujeres que legalizaron su permanencia de un total de 6.448 ecuatorianos.

La etapa de selección de la muestra correspondió a lo que se denomina muestreo bola de nieve donde se escogieron mujeres por características muy generales como la edad, el estado civil, la profesión etc.

El cruce de las variables antes mencionadas dio un total de 8 mujeres escogidas a partir de información obtenida en la Embajada de este país y en los contactos cercanos al investigador. A la hora de recabar información, la posición del investigador fue estratégica a través de un acercamiento a las informantes en determinadas situaciones y conversaciones informales en relación a tópicos generales.

El estudio se realizó entre Diciembre de 2000 a julio de 2001. El trabajo de campo, en tanto, se desarrolló durante los meses de Enero a Marzo del 2001 y consistió en la participación en conversaciones informales con varias mujeres y finalmente una o dos entrevistas en profundidad a las ocho mujeres. 
El perfil de las entrevistadas se detalla a continuación:

\begin{tabular}{|l|l|l|l|l|l|l|l|}
\hline $\begin{array}{l}\text { Estado } \\
\text { civil }\end{array}$ & $\begin{array}{l}\text { Nivel } \\
\text { socio- } \\
\text { económico }\end{array}$ & edad & $\begin{array}{l}\text { Situación } \\
\text { en Chile }\end{array}$ & origen & ocupación & estudios & $\begin{array}{l}\text { Razones } \\
\text { para } \\
\text { migrar }\end{array}$ \\
\hline soltera & bajo & 25 años & Sola & $\begin{array}{l}\text { Semi - } \\
\text { urbano }\end{array}$ & $\begin{array}{l}\text { Empleada } \\
\text { doméstica }\end{array}$ & Técnico & Laborales \\
\hline $\begin{array}{l}\text { Casada } \\
\text { chileno }\end{array}$ & alto & 30 años & Familia & urbana & asesoría & Post-gradol & familiares \\
\hline soltera & alto & 26 años & Sola & urbana & Consultorí & Post-grado & educación \\
\hline $\begin{array}{l}\text { Casada } \\
\text { ecuatoriano }\end{array}$ & medio & 35 años & Familia & urbana & servicios & Técnico & Familiares \\
\hline $\begin{array}{l}\text { Casada } \\
\text { ecuatoriano }\end{array}$ & bajo & 20 años & sola & rural & $\begin{array}{l}\text { Empleada } \\
\text { doméstica }\end{array}$ & $1^{\circ}$ medio & laborales \\
\hline $\begin{array}{l}\text { Casada } \\
\text { chileno }\end{array}$ & medio & 32 años & familia & urbana & gobierno & Universit. & familiares \\
\hline $\begin{array}{l}\text { Casada } \\
\text { ecuatoriano }\end{array}$ & bajo & 40 años & sola & $\begin{array}{l}\text { Semi - } \\
\text { urbana }\end{array}$ & $\begin{array}{l}\text { Emp leada } \\
\text { doméstica }\end{array}$ & 5º́sico & laborales \\
\hline $\begin{array}{l}\text { soltera } \\
\text { alto }\end{array}$ & 26 años & sola & urbana & $\begin{array}{l}\text { Profesional } \\
\text { medicina }\end{array}$ & Post-grado & Educación \\
\hline
\end{tabular}

El muestreo cualitativo se relaciona con las diversas situaciones a enfocar en la investigación (diversos constructos para entender mejor el significado) La muestra cualitativa como lo señala Goetz y Lecompte(1988) se caracteriza por sus condiciones de adaptabilidad y flexibilidad, esto quiere decir, que los sujetos se escogen por su traducibilidad y complejidad más que el de la generalización. Ruiz Olebuénaga (1996:65 ) señala que la muestra en un tipo de investigación cualitativo exige que el investigador se coloque en la situación que mejor le permita recoger información relevante para el concepto o unidad de análisis en base a dos criterios: cantidad (mayor cantidad de perspectivas) y la calidad (riqueza de la información) Sin embargo dicha muestra no puede predefinirse con anticipación.

Las informantes claves además se escogieron en función de su comparabilidad y complejidad; de tal manera que los distintos sujetos que componen la muestra se lograron en función de una variedad de aspectos como son su estructura familiar, la ocupación, razones para migrar etc., y por lo tanto un mayor número de unidades para el análisis. 
Los criterios de selección de la muestra se fundamentaron en gran medida bajo un criterio intencional de confianza expresados en varios tipos de muestreo o selección de unidades de contenido. Dichas unidades de información se seleccionaron en función de la riqueza en la información. Por ejemplo:

- Casos desviantes o extremos.- que ejemplificaron características de mayor interés.

- Muestreo de intensidad.- Se escogieron expertos experienciales

- Muestreo de variedad máxima.- casos dispersos en los que se observan comunidades existentes

- Muestreo de casos críticos.- Ejemplos significativos que identifican puntos críticos

Una vez generada alguna información con los criterios antes señalados como riqueza, traductibilidad, complejidad se fue categorizando, codificando y analizando datos en distintas etapas y situaciones y con ellos se fue confeccionando categorías de personas o sucesos para profundizar. La única preocupación estuvo centrada en recoger la mejor información; por lo tanto fue necesario ubicarse en la mejor posición posible para recoger información sobre distintas unidades o dimensiones.

El diseño metodológico estuvo ajustado sobretodo a la profundización de fenómeno y no a su extensión por lo tanto, la muestra fue intencionada, producto de una selección de casos según el propio criterio del investigador o de algún experto, de modo de seleccionar algunos casos que resultaren "típicos"o "atípicos". Este tipo de muestra perfectamente se utiliza cuando el nivel es exploratorio y lo que se desea lograr es el trabajo con "informantes claves" sobre situaciones específicas.

\subsection{Recolección de información}

\section{Entrevista en profundidad}

La recolección de datos se realizó a través de entrevistas en profundidad acerca de distintos aspectos que intervienen en el tema tales como la antesala al traslado, las redes familiares o 
sociales, las distintas etapas desde la llegada hasta la inserción social y laboral, las expectativas, etc.

Los distintos tópicos que se trataron en las entrevistas en profundidad se relacionan a modo general con:

\section{Dinámica de la migración:}

- reconstrucción de episodios, situaciones y anécdotas de su tránsito a Chile

- la intervención de redes sociales en el país de origen y el de llegada

- principales mecanismos adaptativos

Inserción en Chile:

- Estrategias usadas en la inserción socio-laboral

- Mecanismos fortalecedores del proceso

\section{Identidad Cultural}

- configuración d:e la identidad cultural a partir de situaciones, encuentros y desencuentros en torno al sí mismo y el otro

\section{Identidad de Género}

- Percepción sobre Género y relaciones de poder y control

Cuando se utiliza la entrevista para reconstruir la realidad de un grupo social - inmigrantes ecuatorianos-, los entrevistados individuales son tratados como fuentes de información en base a variables o ejes temáticos. Al utilizar las técnicas de la entrevista en profundidad,

por lo general se sostienen diferentes supuestos pero el entrevistador no conoce de antemano qué preguntas resulta adecuado preguntar. Las respuestas a esta problemática se considera que surge de la entrevista misma, del contexto en el cual sucedieron y del grado de armonía que el entrevistador pueda establecer.

\subsection{Plan de Análisis de los datos}

La investigación realizada recoge el habla de sujetos involucrados en el proceso migratorio Ellas plantean sus percepciones respecto de sus experiencias, les atribuyen determinados 
sentidos y van buscando comprenderlo en el marco de lo que significa emigrar y del contexto social en el que se desenvuelven.

El análisis de la información se hizo a través del análisis del contenido de los discursos producidos por mujeres de distintas condiciones sociales y educacionales. Dicha información se produjo a partir de entrevistas en profundidad.

Respecto al ordenamiento y análisis de la información, se rediseñó en distintas etapas y bajo la necesidad de volver a los datos símbolos, comunes, conversables y participables de los distintos momentos y situaciones vividas por los individuos.

El lenguaje se convirtió en un instrumento de aproximación y escaneamiento de la realidad en este estudio descriptivo e interpretativo del fenómeno; por lo tanto necesitó volverse operativo en la medida en que se necesitaba la descripción precisa del fenómeno por parte de los sujetos para volverlo más comprensivo en función de los contenidos que se declaraban y de las relaciones que evocaban.

Por lo tanto el lenguaje como arsenal de aproximación estuvo centrado en: descripciones, viñetas y narraciones.uego de esto, se construyeron categorías analíticas, utilizando un sistema flexible para poder ir reconstruyéndo en función de nuevas observaciones.Lo que se buscó fue formar categorías sobre dominios.

El análisis estuvo centrado en: El descubrimiento de las características comunes o no de un fenómeno, o sea su contenido. Lo segundo consistió en la aplicación de reglas para identificar y trasmitir dichas características y formar codificaciones y descodificaciones 


\section{Matriz del Análisis}

\begin{tabular}{|c|c|c|}
\hline Dimensiones y variables & $\begin{array}{l}\text { Análisis de los principales hitos } \\
\text { discursivos }\end{array}$ & Selección de textos \\
\hline $\begin{array}{l}\text { La antesala de la migración } \\
\text { - } \quad \text { Características } \\
\text { - } \quad \text { demográficas } \\
\text { - } \quad \text { Información adquirida } \\
\text { - } \quad \text { Nivel de preparación } \\
\text { - } \quad \text { Redes para trasladarse } \\
\text { - } \quad \text { Objetos simbólicos } \\
\text { - } \quad \text { Nivel de expectativas } \\
\text { - } \quad \text { Llegada }\end{array}$ & & \\
\hline $\begin{array}{l}\text { La } \text { Inserción } \\
\text { - } \quad \text { La búsqueda } \\
\text { - } \quad \text { Redes en el proceso } \\
\text { - } \quad \text { Mecanismos de adaptación }\end{array}$ & & \\
\hline $\begin{array}{l}\text { La aculturación } \\
\text { - } \quad \text { Costumbres, rutinas y hábitos } \\
\text { - } \quad \text { El sentido de las cosas } \\
\text { - } \quad \text { Códigos incorporados }\end{array}$ & & \\
\hline $\begin{array}{l}\text { La identidad } \\
\text { - } \quad \text { La relación con mí misma } \\
\text { - } \quad \text { La relación con el otro } \\
\text { - } \quad \text { El sentido de lo primario }\end{array}$ & & \\
\hline $\begin{array}{l}\text { Identidad de Género } \\
\text { - } \quad \text { Control del destino del dinero } \\
\text { - } \quad \text { División sexual del trabajo } \\
\text { - } \quad \text { El control de la sexualidad }\end{array}$ & & \\
\hline
\end{tabular}


Revista Mad. No.4. Mayo 2001. Departamento de Antropología. Universidad de Chile http://rehue.csociales.uchile.cl/publicaciones/mad/04/paper04.htm 


\section{PRESENTACION Y ANÁLISIS DE RESULTADOS}

\subsection{Crónica de un viaje}

Dado que un viaje implica trasladarse desde un punto de partida hacia uno de llegada, con el previo conocimiento de un itinerario y la certeza de un retorno inmediato; la migración, en cambio supone un movimiento, un desplazamiento con una calidad de tiempo y de acontecimientos no previstos. Este tránsito supuso para este grupo de mujeres un ejercicio permanente con su historia, un caminar entre códigos lingüísticos distintos, una identidad precisada a reconstruirse. 'Uno siempre va a estar en comunicación pero uno no sabe cuando los volverá a ver. Solo Dios sabe cuando será y con tristeza se despide uno. (A.pg7.p41)

Gregorio Gil (1999) Establece que gran parte de la migración de mujeres en la actualidad tiene su base de explicación en procesos de desigualdad en el desarrollo del capitalismo y como consecuencia la migración de mujeres responde a una forma de articulación de países emisores de mano de obra con países de mayor diversificación económica y el empleo de éstas en bolsas de trabajo con gran demanda para población extranjera. El grupo doméstico se transnacionaliza al utilizar la estrategia de la migración internacional como necesaria en su proceso de reproducción y producción frente a la demanda laboral y ocupacional dado en el contexto económico globalizado.

\section{¿Quienes son? ¿Qué hacían?}

El análisis sobre la motivación de las migrantes ecuatorianas se planteará sobre la base de un hecho colectivo, es decir que ellas reportan lo que viven, no como sujetos con una lógica individual y racional carente de género, sino más bien como parte de un tejido multirelacional y dimensional en que están integradas.

Se ha de tomar en cuenta dos cosas: lo primero es que como miembros van a reportar diferentes roles y funciones a partir de edad, lugar, estructura de parentesco que van a determinar distinta posiciones en relación con la producción y reproducción. Lo segundo es 
que dentro del grupo doméstico están incluidas también relaciones de poder unidas con aspectos ideológicos.

Una vez reconstruidas las características socio-demográficas de este grupo de mujeres es posible determinar ciertas variables de edad, procedencia, grado de escolaridad, estructura familiar, factores socio-culturales, y del grado de desempleo por sexo en su país. A continuación, se describe el total de la muestra que participó en el estudio con sus respectivas características :

"Yo tenía diecinueve años, estaba casada y tenía un hijo, me iba muy mal en mi matrimonio y decidi emplearme en la embajada, (B. p.6, pgl)

"Yo soy soltera, tengo 26 años, en Ecuador trabajaba en una peluquería. Antes no trabajaba, mi papá tenía un negocio de distribuidora de gas y yo pasaba ahí y era mantenida de ellos como estudiaba; me puse a trabajar, me fui a a trabajar en una peluquería porque me había graduado de eso. Estuve trabajando y luego me volví a donde yo vivía a terminar el colegio (A,pg3.p17)

"Tengo 23 años, tengo dos niños allá y un marido. Le ayudaba a mi papá porque tiene finca de cacao y trabajaba junto con él y mi marido también trabaja allá (J,pgl.p.6)

"Total llegué a mi casa y mi papi me conversa, que Chile estabaBueno; yo trabajaba allá pero no ganaba mucho, solamente para mis golosinas me alcanzaba, ni siquiera para arrendarme un cuarto $(R, p g 1, p 4)$

"Tengo 40 años, Soy de Machala, trabajé en una fábrica de colados y maicenas para niños ...No, no me alcanzaba nada porque tengo niños grandes; tuve que darles los estudios y mi marido no me apoyaba porque quedó sin empleo" (D,pg1.p1)

" Soy de Guayaquil, estudié economía en la Universidad Católica, me casé con un abogado chileno allá y decidimos venirnos a Chile porque mi marido quería desarrollarse profesionalmente acá” (C,pg4.p17)

"Soy Quiteña, estudié medicina y me gradué como médico general allá, viví con comodidades y vine a Chile para hacer un postgrado, no tengo ningún compromiso familiar aún” (K,pg2,p13)

"Soy de Ambato, tengo 38 años, vine con mi marido y dejamos 3 hijos a cargo de mi hija mayor. Yo era ama de casa pero a partir del último año ya no nos 
alcanzaba para nada y decidimos venir los dos para trabajar yo también" (R,pg1.p4)

La experiencia de haber migrado antes, también fue reportada como una buena preparación para saber cómo afrontar este proceso nuevamente; experiencia que faculta a las personas a desarrollar iniciativas tendientes a superar carencias materiales, emocionales, afectivas.

"Cuando regresé a Quito, después de vivir cinco años en Italia y después comencé a estudiar de nuevo, me metí a un curso de chofer y me dediqué mucho a mi hijo y a mi mamá, tenía plata en el banco y prestaba plata a intereses" (V,pg1,p3)

Respecto del análisis de la composición por edad de las mujeres emigrantes, cabe hacer algunas reflexiones: La mayoría comprende edades que van de los diecinueve años hasta los cuarenta. La primera mitad son solteras y sin compromiso; la otra mitad tienen compromiso o han formado familia de procreación en su país de origen y por lo tanto, se ha transformado el núcleo familiar o se han trasladado junto a su familia constituida o parte de ella.

La mayoría terminó su enseñanza media y se dedicaron a diversos oficios como la agricultura, el comercio, auxiliares de peluquería, recibiendo un salario mínimo a diferencia de otras que se desempeñaron como dueñas de casa sin una remuneración y sin posibilidad de aportar monetariamente para la reproducción material de su hogar. Una pequeña parte corresponde a mujeres con estudios universitarios que habían tenido experiencia laboral en su país de origen.

\section{Porqué viene la gente?}

"Entonces yo le dije a mi amigo que sí, que sí me venía que me explicará todo como es, sacar el pasaporte y de ahí decidí venirme con él(J,pgl.p3)

"Ella había estado haciendo los papeleos y se había encontrado con mi papá y le había dicho que la hija se va para Chile y mi papá me llamó y me dijo: como tú siempre has querido irte para otro lado y ahora se presentó la oportunidad,(A,pg1.p3) 
Se destacan: la subsistencia, el logro de objetivos económicos o materiales, una cierta identificación con la sociedad chilena, cercana en el idioma y características culturales respecto de las de su origen además de la auto-realización de la persona como motivaciones fundamentales para venir. Una situación implícitamente ligada al carácter obligatorio del traslado por trabajo o profesión son las expectativas alcanzadas en el país de origen.

Sin embargo, como se menciona anteriormente, el estudio de la causalidad de la migración de las mujeres no se refiere a un hecho aislado de su condición de género o de su rol o función dentro del grupo familiar o las condiciones socio-estructurales propias de su país de origen "O sea como mujer yo trataba siempre de buscar lo mejor y hacer un poco más para algún día volver a salir del país.(B.pg3,p18)

En la descripción que se hace a continuación sobre las ecuatorianas migrantes se llega a la conclusión que la mayoría dejaron atrás hogares y familia (padres/marido/hijos), un entorno (social,geográfico) y se enfrentaron al desafío de conseguir mayores y mejores condiciones de vida teniendo que adaptarse a otro medio.

Respecto a la decisión de venir a vivir a Chile definitivamente, cabe anotar que un menor segmento de ellas declaró haber tomado esta decisión debido a que sus parejas eran chilenas y una vez reestablecida la democracia debieron asumir como destino final este país que ofrecía mejores ventajas especialmente para jóvenes profesionales.

"Bueno, el tema es que me entristecía el pensarme lejos de lo mío pero cómo Cristián era chileno y habiendo estado ausente muchos años en Ecuador, tenía mucha nostalgia de su país, de su familia y sus amigos. (C,pg1.p4)

Además, se evidencia el caso de mujeres profesionales que han venido a Chile interesadas en obtener un mejor nivel educacional a través de estudios de postgrado, o para trabajar en el área de la salud.

"Yo tenía algunos amigos colegas que estaban cerca de dos años y que encontraron aquí lo que enEcuador no se estaba dando para los médicos. Como médico general no haces mucho y vine a hacer una pasantía en un hospital y luego me gané una beca en Gineco y aquí voy para los cinco años" (K,pg1,pg6) 
Como se mencionó en el primer capítulo, la explicación a este fenómeno parece relacionarse con el hecho de que al existir fuertes necesidades económicas, sociales o educacionales hay mayor disposición a asumir riesgos, además de la circunstancia de que en este viaje sin proponérselo tendrán la posibilidad de conocer a sus futuras parejas o constituir nuevas uniones.

\section{Qué dejaron}

La mayoría de las mujeres casadas que fueron entrevistadas dan cuenta de una estructura familiar que se reacondiciona ya sea porque uno de los dos o los dos (padre o madre) se ven forzados a abandonar el hogar motivados por la falta de empleo o de mayores ingresos o hijas que dejan una red de parentesco y vinculación social. Se constató que las mujeres con familia de procreación tuvieron que dejar a sus hijos al cuidado del marido o familiares cercanos como son los abuelos maternos y dependiendo de la edad, las hijas mujeres "toman el relevo de sus padres" y se encargan de las funciones esenciales de la crianza y el cuidado de los más pequeños,esperando el envío de un dinero

“ Ella me decía mamá ándate no más y tú después nos mandas la plata y yo les voy a cuidar a mis hermanos, no te preocupes (R,pg4.p23)

hablé con mis papás por el tema de mis niños y mi papá me dijo que me viniera que por los niños no te hagas problemas(J,pg1.p3)

Dejan además una cadena de incertidumbres respecto a las condiciones reales respecto al país, a los suyos (maridos, hijos, padres), una forma y un ritmo de vida.

"Llo único que falta es el trabajo porque si hubiera trabajo nosotros no saliéramos del país; porque habiendo trabajo ya los esposos ya trabajan y están las esposas en la casa esperando que los esposos les lleven el dinero para los niños(R.pg2.p15)

\section{Qué información tenían}

Interrogadas acerca de lo que conocían sobre el país de destino, las mujeres con escolaridad baja o media concuerdan en que lo conocían referencialmente. Dicha situación se explica debido a que tan sólo en lo últimos años Chile se transformó en un país de tránsito o de destino de migración laboral o profesional debido a que tradicionalmente se había mirado 
como países receptores a Estados Unidos y Canadá. "No tenía idea de Chile, nunca había oído hablar de Chile; lo que sí sabía era de Estados Unidos, España e Italia> No sabía cómo era, si el trabajo era bueno.” (A;pg 1.p.5)

La información obtenida en algunos casos es de primera mano a través de una suerte de "ganchos" que dejan correr un río de información en unir y venir permanente de "Sí conocía porque unos amigos estaban acá y llamaban para allá e incluso hablé con uno de ellos y él me dijo que sí que estaba bien; entonces yo también me voy. (J, pgl,p4)

Es probable también que una vez instalado alguno de los miembros de la familia, éste (a) haga de puente a algunos de ellos como puede ser el caso de padres, hijos o hermanos. "Yo sí ayudé a mi hija para que venga. (R,pg3.p18)

\section{La preparación}

Respecto a la preparación previa que requiere trasladarse a vivir en otro país, se puede concluir que aquellas con un menor nivel educacional y atraídas por una suerte de paraíso laboral dan cuenta de haber tenido menos tiempo de preparación.

"No, no tuve mucho tiempo para pensar no sabía nada, lo único que sabía es que tenía que trabajar en una fábrica y que era un trabajo suave y yap... me voy y hago experiencia en otro lado(A.pg1.p8)

Mientras que para un segmento de mujeres con mayor nivel educacional la situación requería mayor preparación entendiéndose el traslado como un momento de gran esfuerzo físico y mental con episodios de riesgo y dificultad.

"Sí que fue difícil la decisión, estuve mucho tiempo reflexionando porque si bien siempre habíamos hablado del tema, me preparé lo mejor que pude, terminé mi carrera en el último año, disfruté de todo y cuando estuve lista psicológicamente, tomé mis petacas y me vine" (C, pg2.p12) 


\section{Con quién vine}

El modo cómo se llega al país de destino va a depender en gran medida de la participación de agentes y agencias de información, de las restricciones o facilidades o requerimientos legales en relación a las visas y permisos de trabajo, de la demanda en las bolsas de trabajo. Un hecho común es la participación de "vínculos" generadores de confianza que sirven de apoyo en la decisión; sean éstos amigos, familiares, conocidos o conocidos de conocidos. "O sea decía que aquí era bueno para trabajar especialmente para la mujer, él se prestaba para hacer todos los trámites y que la plata le den a él (A.pg3.p2)

Es de anotar que la mitad de las mujeres entrevistadas vinieron a Chile sin su familia constituida, acompañadas por un amigo, un familiar cercano, mientras que la otra mitad lo hicieron con sus respectivas parejas. "Bueno, mi pareja tenía unos amigos que estaban aquí y ellos le dijeron que si quería venirse que se venga y me vine acá (B.pg1, p7).

La presencia y participación de las redes de "conocidos" es un hecho capital en el proceso migratorio ya que actúan como catalizadores del proceso con su participación directa ya sea como el que los trae, acompaña en el viaje o los ubica temporalmente.Que venga. Que aquí había un Señor ecuatoriano, que tenía una fábrica y que coge a todos los ecuatorianos.(A,pg1.p3)

Muchos de estas relaciones circunstanciales son solamente el "gancho" o nexo que hace del flujo de gente migrante un modo de vida. "Porque un amigo ya estaba aquí y me dijo que era bueno. y este supuestamente no ganaba nada pero en la realidad él se financiaba los viajes trayendo gente 'el vino con la plata nuestra (J.pg1.p2)

Es probable además, la existencia en el país de agencias legales o ilegales encargadas de colocar en el mercado laboral a mujeres Ecuatorianas o Peruanas como asesoras del hogar con el consiguiente cobro de una comisión. "Cuando estaba en Ecuador mi amigo me 
contó que había una señora Chilena que se encargaba de enseñar a las personas que iban a trabajar en casa todo lo que necesitaban saber y además les conseguían” (J,pg1,p7)

\section{Qué traje conmigo}

Tratándose de una travesía cargada de incertidumbre, la mayoría de las entrevistadas declararon haber traído las cosas más necesarias esto es algunas mudas de ropa, fotografías, cartas y algún objeto con algún valor sentimental. "Yo traje lo más necesario en una maleta porque como veníamos en bus <. fotografías de mis hijos” (J,pg3.p21)

Sin embargo, sin tener claro el tiempo que permanecerán y el espacio donde vivirán, el habitar un lugar para trasformarlo en un lugar de identidad no parece ser un aspecto que se ha de tomar en cuenta antes de partir. "Yo había traído algunos cuadros de allá que me gustaban y que tenía muchos recuerdos, algunas cosas de casa pero en general cosas muy chicas y que tenían un valor sentimental (C.pg3.p14)

La fuerza, el valor, el coraje son valores que la mayoría de las mujeres reportan haber traído consigo desde el momento en que partieron. Sentimientos que van a transformarse en herramientas sicológicas con las que ellas afrontan el hecho de la migración. "Bueno, yo el valor que encontré fue al verle a mi hijo y pensaba que si perdía esa oportunidad, perdía todo (B.pg4, p22)

\section{Qué expectativas traían}

Las expectativas se relacionan con aquellas situaciones ideales que uno está en deseo de lograr y para ello emplea toda la energía posible para llevar a cabo tales propósitos. "En esa época yo estaba casada y si yo iba a hacer lo que hacía en mi casa( B. p7, pg1)

Sin embargo, se traduce también en una sobrevaloración de las condiciones existentes y en subestimar los obstáculos que se habrán de afrontar. Por lo tanto, mientras más alto sea el 
nivel de expectativa, mayor será la carga emocional que acompañará cada una de las experiencias.

En salir, en irme, en hacer experiencia, irme a trabajar pero nunca imagine que el trabajo iba a ser tan fuerte, o sea yo pensaba que el trabajo iba a ser como yo había trabajado en Ecuador; pero no pensaba que uno iba a otro lado a sufrir. (A.pg1.p5)

\section{Que encontraron}

Se podría resumir la llegada en varios episodios: 1) las circunstancias en las que se llega (hora, día, lugar, primeros contactos 2) El primer momento (búsqueda de trabajo, experiencias traumáticas, redes 3) la búsqueda de trabajo. Una vez que se ha emprendido la travesía, la realidad va instalándose en la emoción llenándola de aventuras, y episodios dignos de historias de hazañas.

"Fue un Domingo que llegamos me robaron la y me quede con lo puesto. y de ahí si que me iban las lágrimas y estos amigos se acercaron y me dijeron: ya, no te preocupes como quiera hemos de hacer.(J,pg3.p15)

Pasado el momento de expectación respecto de cómo será el país de destino, las entrevistadas declararon vivir sensaciones contradictorias, puesto que una vez aquí se enfrentan con sentimientos de soledad, de angustia ya que han dejado atrás todo lo que les brindaba seguridad y protección y deben ahora comenzar a procurarse lo más básico como es el tener un techo seguro y la posibilidad de un trabajo.

Creo que el comenzar fue medio raro porque uno no sabe muy bien a lo que se va a enfrentar, estás como disfrazando ideas y pensamientos, todos positivos desde luego.(C,pg2,p10)

Hay una tarea primordial en los primeros días que requiere un gran esfuerzo, esto es el acondicionamiento de un espacio de habitación"nos cambiamos a nuestro departamento y estaba vacío, sin nada, había que llenarlo con tantas cosas.(C,pg3,p13)

Las residenciales, las casas conventillos, los albergues son los lugares que gran parte de las entrevistadas de estrato medio bajo tuvieron que asumir primero; en estos lugares se tejen las más inusitadas experiencias de vida, muchas de ellas traumáticas y con un trasfondo de solidaridad humana 
"nos dio la dirección de un albergue de un padre italiano y hablamos con el Padre y él nos dijo que teníamos que pagar mil pesos diarios.... El cuarto teníamos que compartir con otra chica y a la seis de la mañana teníamos que salir a buscar trabajo y llegar a las siete. y salir a buscar trabajo y hacíamos lo que nos decían(Anpg4.p25)

Las mujeres segmentadas como migrantes laborales, en general son las que han debido atravesar episodios muy complejos y están expuestas a sufrir una serie de acontecimientos traumáticos en el primer momento porque la mayo ría no cuentan con mayores recursos para mantenerse hasta encontrar trabajo

"Ya no teníamos dinero por eso caminábamos todo el día porque no teníamos plata para la micro y comprábamos pan y llenábamos una botella de agua para caminar bastante (A.pg2.p14)

Además, muchas veces se ven expuestas a situaciones límite ya sea porque se han dejado llevar por un sentimiento de excesiva confianza y son presa fácil de aventureros que trafican con sus necesidades; sin embargo es aquí donde ellas encuentran las primeras señales de apoyo.

" este chico compadeciéndose de nuestra situación, le había reclamado al otro que cómo nos había hecho esto, de traernos y dejarnos botadas. Luego él mismo nos llevó a comer, nos dio plata y nos llevaron a una discoteca y yo me veía sola y ahí me puse (A.pg3p23)

La búsqueda de trabajo fue un ejercicio agotador para las mujeres migrantes laborales ya que sin este salvoconducto no podían siquiera pensar en la posibilidad de permanecer mucho tiempo en Chile.

"En realidad les rogamos que nos cogieran, que por lo menos nos den la posibilidad de un techo porque ya no teníamos dinero, porque teníamos miedo de estar más tiempo sin trabajo. porque si pagábamos el hotel, ya no teníamos plata ni para comprar el pan (A,pg3p23)

Las bolsas de trabajo para estas mujeres generalmente son como asesoras del hogar o trabajando temporalmente en la fruta

"Esta señora se portó bien conmigo, me enseño comidas, me regalo ropa, me enseño todo lo que debía conocer. >Ellas me dijeron, quédate tú mejor y la señora ya me conoció a mí y me dijo que bueno.(J,pg3.p16) 


\subsection{Domesticando el circuito}

\section{La Inserción}

Dado que la gran mayoría de mujeres definen el proceso de la migración como un evento complejo y traumático. El cómo van organizando su experiencia? mayoritariamente distinguen un primer momento frente la evidencia de diferentes formas culturales entre Chile y Ecuador, palpados cuando se ha arribado al lugar de destino. El primer obstáculo a salvar es la sensación de sentirse un "extraño" entre las cosas que allí suceden y las formas por uno conocidas.

Si claro, cuando uno está recién llegado siempre extraña. Todo. Las costumbres que por ejemplo uno se levanta y aquí está obscuro, por ejemplo el vocabulario, que no se entiende. Primero el ambiente y después el idioma eso me costó a mí. Para mí fue como empezar al principio porque no le entendía nada (J.3.p14)

Como se mencionó anteriormente algunas de estas mujeres segmentadas como migrantes laborales no calificadas han venido desde su país de origen con promesas de un ingreso mayor a los trescientos dólares, se embarcan con lo justo y al llegar a Chile se encuentran con una realidad muy distinta no solamente por las condiciones reales de trabajo e ingreso sino porque desconocen aspectos culturales muy básicos como la ropa usada en las distintas estaciones o el dinero que necesitan para llegar a establecerse.

Para una semana teníamos comida, porque nos pagaban a fines de mes y un señor de ahí nos dijo que nos podían regalar tomates y cosas que tenían sembrado y de ahí pasamos. Habían tres camas y dormíamos como siete y sola yo de mujer y ahí nos acomodábamos como quiera y como ya se habían acabado las manzanas y habían solo Kiwies, nos fuimos prácticamente a robar las manzanas y nos tocó caminar una hora a pie y cruzar unos cerros hasta llegar con mi hermano y dos amigos máss(J,pg1,p11)

Respecto a las mujeres migrantes calificadas, su condición de llegada al país es algo distinta porque vienen conscientes desde su país de las dificultades que habrán de afrontar y por lo tanto vienen algo mejor dispuestas tanto en recursos como en preparación para la etapa más dificultosa que es la búsqueda de trabajo

Sin embargo, sea como fuere lo apremiante en la búsqueda de trabajo para las mujeres calificadas y no calificadas, el trabajo es una condición necesaria para la permanencia en el 
país de acogida y para la real inserción en éste porque este ejercicio la dotará de sentidos y validará su condición de extranjeras. De tal manera que solo cuando este hecho se ha producido se podrá experimentar realmente el proceso de inmigración

"Creo que este punto es muy importante para cualquier persona que migra a otro país ya que el trabajo no solamente es lo que recibes por un trabajo determinado, con el cual apoyas económicamente a una familia, es la única manera de que den la oportunidad de integrarte a un país, de establecer vínculos reales”(C,pg2.p16)

En general, las redes de contacto del mismo país, parecen ser primordiales a la hora de encontrar trabajo, ya sean anteriores o producto de las circunstancias. Las mujeres empleadas como asesoras del hogar ven en la posibilidad de trabajar en casa particular una situación favorable debido a que es la única manera que tienen para ahorrar y ayudar realmente a su familia ya que de otra manera sería imposible

"no sabíamos que acá se tenía que trabajar en casa y dije, yo no sé hacer nada, no sé trabajar en casa y él dijo, ahí van a estar mejor porque así no tienen que gastar en nada porque por lo menos tienes donde quedarte. Es lo que más nos resulta a nosotros porque sacamos líquido entero para así poder mandar a nuestro país (R,pg1.p2)

Los rasgos culturales entre chilenos y ecuatorianos se acentúan en el primer momento. Esto se hizo palpable especialmente en el caso de las migrantes ecuatorianas que encontraron trabajo como "nanas" y se sintieron obligadas a sintonizar con una serie de formas, conceptos y relaciones no conocidas hasta ese entonces.

Por ejemplo en la casa, la organización de la casa que por ejemplo yo organizaba la casa de una manera y mi jefa venía y decía que no estaba bien, o y después todas las cosas de arreglo de casa, de adornos todo, todo es distinto; por ejemplo yo una vez le hice una ensalada y ella me dijo que no le gusto, es decir, primero le hice una ensalada y no le gusto, le puse tomate, aguacate y choclo y me dijo que no le pusiera así que a ella le gustaba en fuentes separadas . (J.'p3.p14)

Esta relación dialéctica entre una cultura y otra es un tema capital para el migrante Tomando a Goodenouh, aprender a sintonizar con una cultura está en relación con un aprendizaje de normas para decidir lo que es, para decidir lo que puede ser, lo que no se siente, para decidir que hacer y cómo hacerlo. 
El contacto con otra cultura también permite ver los diferentes sistemas de relaciones. Esto se hace evidente respecto al tema del trabajo y las relaciones de inclusión y exclusión que la mayoría de las mujeres entrevistadas experimentaron al sentirse discriminadas en el trato diario. Situación que se describe de formas muy particulares en cada una de ellas sea a partir del sueldo que les pagan, el trato displicente, el prejuicio y la subvaloración con relación a su calidad profesional

"Se exporta un managment y bueno a partir de ahí estás descolocado, es decir, no creo que no exista trabajo para los extranjeros pero solo para determinados oficios y empleos menores”, (C,pg4.p18)

La posesión o algunos derechos y privilegios dependen de la concordancia con alguna clase de calificación. Tales como edad, sexo, función reproductora, temperamento y actitudes intelectuales junto con otras diferenciadas en habilidad, conocimientos experiencia . Tales desigualdades tienden a hacerse mayores en sociedades donde la especialización ocupacional está altamente desarrollada

Yo sabía que iba a trabajar en casa pero no me imagine que fuera a ser tan distinto de cómo es en Ecuador, ahora que me pongo a pensar allá se trabaja hasta el Sábado y aquí salgo los Domingos y aquí se trabaja hasta la noche, uno aquí pierde un poco sus derechos y se siente disminuida del resto de gente.(J,pg3.p16)

La flexibilidad con la que uno vaya incorporando o frenando esta dinámica cultural parecería estar en relación con el carácter forzado de la migración, entendiéndose de antemano que toda migración es forzosa por la razón que fuere pero que el valor asignado va a depender de cuánta determinación sintió la persona a la hora de tomar la decisión.

Muchas cosas no toleraba y no soporté al principio, por ejemplo la mentalidad de la gente, l os patrones para educar a sus hijos, los valores y creencias, la forma de ver la vida. (C.pg2.p8)

Es decir, que el grado de libertad con la que se tome la decisión va a influir en que éste se convierta en un proceso doloroso y cargado de frustraciones, pero en cambio, si las presiones más allá de lo estructural, las valora como importantes y necesarias, el sentirse como extraño y el ajuste cederán de manera armónica. Cabe añadir algunos de los conceptos trabajados por Germani respecto de la migración internacional donde establece 
que la posibilidad de una mayor o menor inserción cultural, va a depender de la posición relativa del lugar de origen del migrante y su lugar de destino en cuanto a variables de prestigio y distancia social entre el uno y el otro país. Dicho de otro modo, si existe en el migrante una mayor integración y valoración cultural del país de origen, esto determinará una integración parcial o transitoria y fomentaría una cierta distancia cultural participando tan poco como sea posible y logrando finalmente una mínima asimilación cultural en el país de destino, mientras que cuando la valoración del país de origen es menor, la migración tenderá a ser permanente y la asimilación más fácil. (Germani; 1965: 78)

\section{Adaptación}

Dependiendo de las motivaciones para migrar, el proceso por el cual una persona se integra a una sociedad, a sus reglas, a sus conceptos, a las formas de organizar la rutina se cumple de forma muy diversa y en un lapso de tiempo indeterminado para cada una de las personas. Por lo tanto, todos los que emigran serán sometidos a un cambio en sus patrones culturales, un ajuste personal en los distintos órdenes de la vida (laboral social, familiar, recreativo).La situación de vida del inmigrante se traduce en "un esfuerzo dramático de reducción de complejidad. Los caminos que conducen a este hecho son variados pero se pueden agrupar en dos instancias: la conformación de un nuevo ambiente sea laboral, familiar o social, la institucionalización de ciertas pautas adaptativas

Según lo declaran en sus testimonios, la inserción en las distintas áreas fue un paso fundamental en el proceso de integración a la sociedad de acogida ya que fueron descubriendo además de los códigos comunicacionales, las herramientas socioculturales para aprender a enfrentar el futuro.

El proceso por el cual una persona se integra a cada una de estas dimensiones, tiene que ver con la capacidad o habilidad para decodificar una determinada cultura, a través de sus aspectos paraverbales inmersos en el lenguaje.

"Yo llegué a entender ahí que yo estaba completamente adaptada a mi medio pues nunca me había puesto a pensar en las cosas más pequeñas, la forma de decir las 
cosas, lo implícito y explícito.. Por ejemplo, el olor de las cosas viejas o nuevas, el olor de las comidas, bueno, en fin.(C,pg2.p12)

Para Munizaga, esta situación, supone que en cada uno de estos medios (Ecuador-Chile) son diferentes las categorías mentales usadas por los individuos en su comunicación recíproca. La diferencia estaría basada en el grado de abstracción, en este caso tratándose de una sociedad como la Chilena con un grado mayor de complejidad que la ecuatoriana. Esta constituye una de las fuertes barreras que habría que superar en el tránsito hacia el otro medio.

Creo que fue un año más o menos de sentirme extraña. comenzamos a frecuentar amigos pero siempre tenía la sensación de que hablaba muchas cosas que nadie podía reconocerlas, porque utilizaba otros términos y una forma especial de afirmar las cosas, (C,pg3,p16)

Munizaga supone que si el tránsito entre dos formas de vida a través de la migración se hace complejo es porque en el proceso no existirían demasiados caminos estructurados o ritos de iniciación que ayuden al hombre que migra y le señalen la manera de llegar y de adaptarse a este nuevo ambiente

La necesidad de pertenencia a lo más básico, un contacto primario es una de las características principales en la inserción, en donde los que participan entran en relaciones íntimas y personales tales contactos pueden ser los niños con sus padres, grupos formales e informales, los vecinos, amigos, compatriotas e inmigrantes; todos ellos convertidos en un soporte.

Al venir tenía mi hijo Sebastián de dos años y medio, estaba esperando el segundo., mi marido nos dejaba solos casi todo el día, salía con mi hijo a caminar cerca y nadie me hablaba, yo llevaba a mi hijo en su triciclo y los niños jugaban alrededor de él y se dirigían algunas palabras, y yo me instalaba en un banco a mirar y a partir de esos momentos comencé a sentirme bastante sola, temerosa de todos y aumentó mi desconocimiento y descontento (C,PG3.P15)

Sin embargo, a pesar de que se integran a estas redes, llevan la certidumbre de sentirse extraños

"El problema de los amigos y de las cercanías es que tú tienes una vida que pasa por episodios; entonces llegas y no tienes nada de tu historia, nada que te 
identifique, no es que no hayan múltiples cosas en común, porque las hay sino que ellos no pertenecen a esa parte de tu que te dan sentido (C,pg3.16)

El proceso de adaptación reviste de variada complejidad debido a factores socioculturales, como son nivel educacional, diferencias de clase que se transforman en características diferenciadoras y salientes de los diversos estratos sociales y profesionales, especialmente aquellos que se refieren a su comportamiento social, costumbres, patrones de consumo, intereses y actitudes.

Nuevas conversaciones, nuevas caras y recorridos, comencé a mirar el punto de vista de la gente que camina en las calles, comencé a estudiar las características de lagente. Mi hijo mayor se fue luego al Kinder y se relacionó con niños, mi marido también más consolidado el tiempo pasó y las cosas fueron tomando orden (C,pg4,p14)

Un Elemento importante dentro de la inserción es la participación en comunidades de compatriotas ya que obtienen de aquí apoyo y reencuentro con fragmentos de identidad necesarios en la reconstrucción de nuevos sentidos.

bailamos y comemos juntos, por ejemplo sabemos que va haber algo especial, entonces reunimos el dinero y se hace. Cosas que cocinamos y que nos gustan a todos por ejemplo: los patacones o la fritada o arroz relleno pero siempre nos entendemos y ayudamos todos y tomamos cervezas y hacemos bailes en nuestras piezas y la pasamos muy bien(J,pg4.p19)

Lo que sucede ahí adentro es que las personas que migran, mujeres u hombres tienen la necesidad de vincularse a estas comunidades para encontrar apoyo frente a la complejidad, alguna información necesaria y sobre todo construir sentido. Estas comunidades son las estructuras de transición de las que habla Munizaga, cuya función es hacer de puente frente a las experiencias laborales, sociales, a las presiones sicológicas de vivir en un medio extraño y diferente, donde el sentido de la vida es tan frágil como son las certidumbres en relación a la familia o a los amigos.

"chicas que estaban recién llegadas y también se ponían mal y nosotras como ya estabamos más tiempo, entonces nos poníamos a aconsejarle, a apoyarle que así mismo es pero ya poco a poco uno se va adaptando(A.pg4.p28)

La comunicación es la responsable de dotar de encuentros y sentidos a través de la posibilidad de poner en común o intercambiar estados subjetivos tales como ideas, 
sentimientos, creencias, por medio del lenguaje y es ahí donde parece la mujer tener un papel preponderante.

"Todas las semanas nos llamamos, si alguien viene, nos comunicamos todas para saber si no saben de algún trabajo. Nos prestamos las recetas de comida chilena y por ejemplo la una ayuda a la otra o yo les enseño a las dos como se preparan las cosas. Todo eso es por que uno ya sabe lo que ha pasado aquí.(J,pg5.p20)

La nacionalidad por lo tanto se transforma en un vínculo entre los migrantes que si bien comparten ciertos rasgos comunes, como el vestido, el lenguaje, el adorno, frmas de recreación, organización familiar, valores. Lo que los identifica es la idea del "nos" pero no es necesaria la uniformidad.

"Si, por ejemplo cuando comparto con ellos, me hago al ambiente, bailamos, reímos tomamo; yo soy un poco diferente porque me gusta pero tengo otra forma de pensar, me gustan las fiestas pero de repente no más (A,pg3.p15)

La coadaptación es un proceso conjunto, que hace posible la acción o conducta del grupo de iguales (misma nacionalidad). Los individuos a fin de constituir un grupo funcional de cualquier índole y para llevar una vida en común tienen que coadaptar o coordinarse entre sí frente a un propósito en común, que es la necesidad de sobrevivir y adaptarse a través de cierto intercambio de ideas o sentimientos. No todas las formas de co-adapatación social son cooperativas ya que la tolerancia es una forma de adaptación social pero no es cooperación

"En la Navidad ya no se tiene la familia pero se tiene los amigos, son muy importantes, Todos compartimos mucho porque ellos están también lejos y nosotras también. Para mí son muy importantes y nunca me he pelado con nadie, hemos pasado buenos y malos ratos( $J, p g 4, p 18)$

El cambio de las circunstancias diversifica las posibilidades para utilizar determinadas recetas. Tal es el caso de las migrantes ecuatorianas empleadas como asesoras de hogar que han debido aprender a funcionar como tales, sin haber tenido una experiencia previa o el caso de mujeres que han venido a Chile por otros motivos y que han tenido también que cambiar sus rutinas y su modo de vida. Las consecuencias pueden ser la ruptura de los programas muy complejamente estructurados. 
Las estrategias que se encaminan frente a este propósito van a depender de la carga cultural, ideológica, sicológica que acompañe al individuo. Estas pueden ser la conformación de un nuevo ambiente, la institucionalización de pautas adaptativas, la capacidad para discriminar los distintos planos de la vida diaria y la consecuente elaboración de estrategias para relacionarse con los distintos ambientes.

"Claro que al principio se me hizo muy difícil porque no tenía idea de cómo era lidiar una casa, y aquí me he sentido como una madre de familia porque aquí yo atiendo a las personas como si yo fuera la mamá, atiendo a la chiquita.(A.pg6.p38).

La adaptación se define como la modificación paulatina con la cual se adquiere destreza para vivir en un ambiente. Supone un paulatina observación de los aspectos necesarios para actuar en concordancia con los otros; una vez pasada la etapa crítica, donde todo suena extraño, se inicia la etapa de reconstrucción de sentidos cotidianos y es allí, que la capacidad de la persona, más sus rasgos socio-culturales se agudizan para intentar estabilizar su situación. Es necesario aparte de sobrevivir, darle sentido al día a día a través de las ocupaciones económicas, la educación de los hijos, la relación con la familia. “decidí que habían pasado dos años y que debía hacer algo por mí y me matriculé en un MBA en la Universidad de Santiago. (C,pg4.p16)

Adaptarse consiste en interiorizarse en el manejo de ciertos códigos culturales, relacionados con la forma de pensar, la forma de vestir, los atributos de ciertos elementos el sentido que acompaña a las acciones y estos se evidencia en un aprendizaje que se va transformando en rutina. "Yo aprendí cómo uno debe hacer las cosas en Chile para no ser tan extraño, tengo una forma de hacer las cosas que ya no es igual que cuando comencé, que no sabía nada; ahora lo paso mejor"

Cuando hablamos de recetas nos referimos a ideas y comprensiones de cómo hacer las cosas y cuando hablamos de rutinas y costumbres nos referimos a su verdadera realización.

” Me enseñaron como tenía que hacer, me costó mucho a adaptarme y los días sábados llegaba cansada y lo único que quería hacer es dormir y dormir y nada más porque tenía que levantarme temprano y estar de acá para allá todo el día y acostarme tarde y a veces el día se Me hacía corto porque me demoraba mucho en 
las cosas, porque no tenía agilidad pero ahora ya sé como hacer las cosas y me pongo más relajada.(A.pg6.p38).

A diferencia de las rutinas, que nacen de los hábitos en ejecutar recetas concretas, las costumbres tienen que ver con los hábitos de escoger entre las posibles recetas y posibles rutinas desarrolladas.

“ Yo aprendi a ver otras forma de hacer las cosas por ejemplo en Ecuador yo pensaba que a los niños se les debía alimentar con unas cosas y aquí me di cuenta que hay otras costumbres y que las mías, más las que aprendí aquí me servirán para educar mejor a los míos” (J,pg4.p41)

Una vez que se ha establecido una costumbre, los requisitos para ponerla en ejecución se convierten en una restricción que afecta la forma en que otras recetas y costumbres pueden adoptarse con facilidad; es decir, sirve para limitar la forma de las otras costumbres y para limitar las recetas alternativas. "Todos sabemos que en Chile no podemos hacer todo lo que allá hacíamos, por que la gente allá tiene una forma distinta de divertirse y si uno hace eso aquí lo ven mal”(B,pg3.p30)

No obstante, también se copian actitudes, se adoptan criterios vistos como deseables para el medio en el que se encuentran. Situación que se evidencia respecto de la forma cómo se llevan las relaciones ya sea de pareja o entre amigos

Ahora ya no tengo necesidad de mantener una pareja sino trato de adaptarme al ambiente, de vivir al ambiente en el que estoy porque acá no es nada serio y nadie le toma en serio y uno tiene que adaptarse a eso.(A.pg1.p5)

Mis amigos, la mayoría que tengo ya están adaptados y ellos hacen a la cuenta que están en Ecuador, se compran ropa cara, beben, se van de viaje, o sea viven para mantenerse y no ahorrar(A.pg3.p12)

Las pautas y principios dan carácter colectivo e individual a sistemas globales y que se puede llamar pautas de cultura o temas culturales.

sea de la familia o sea cómo que no les importa la familia, no están ni allí con ellos, ni los padres, viven su vida sin importarles el resto pero en 
cambio uno en eso es diferente tiene una forma distinta de pensar, tiene una cultura diferente, digamos uno es más apegado a la familia, a su país, si uno está acá es por necesidad de trabajar, para un mejor futuro y tener algo y eso pienso yo. Tal vez con los términos que utilizan acá a uno ya se le pegan pero solo la imagen exterior o sea aparentemente uno ya se va adaptando, para que le entiendan uno tiene que hablar casi como ellos.(A.pg3.p12)

Finalmente, cada individuo desarrolla a partir de su experiencia su visión personal y subjetiva del mundo y de sus contenidos (tanto lo cognoscitivo como afectivo de sus experiencias); y que Goodenough ha denominado proprioespecto. Dentro de él se encuentran las distintas normas para distinguir, valorar, crear y hacer y lo que él atribuye como sentido de la realidad en la que habita

"soy una persona que si tiene que irse más allá, me voy porque sé que puedo porque soy una persona arriesgada y segura de mi misma, si tengo que adaptarme a Chile y su cultura tengo que hacerlo, aunque sepa que no soy igual, tratar de ser feliz en la medida de lo posible, ya no tengo miedo a nada (B.pg6.p31)

\section{Cuánto tiempo en este viaje}

Respecto al tiempo de permanencia en Chile, la mayoría declaró estar viviendo más de un año. Sin embargo, ninguna de ellas tiene claro el tiempo que seguirá en este tránsito ya que todo depende de las condiciones en el país de origen y especialmente de la situación laboral en Chile. Estoy dos años. Y me voy a quedar un tiempo más hasta que mis hijos estén más grandecitos y luego regresar a Ecuador cuando se arregle un poco más la situación(R.pg1.pl)

Sin embargo, habría que hacer algunas acotaciones al respecto. Lo primero se relaciona con el hecho de que ven a Chile como un país de transito, es decir, una vez vivida la experiencia del tránsito, ésta se convierte en una realidad permanente para muchas de ellas; Lo que significa que hay una suerte de acostumbramiento a esta condición nómada y es probable que por esta razón estén buscando trasladarse a horizontes más lejanos, llevadas por el anhelo de conocer y vivir muchas más experiencias 
Sin embargo existe también la certidumbre de jamás tener una vuelta a "Casa" respecto de aquellas que tomaron la decisión de radicarse definitivamente en Chile".Bueno, son entre siete años más o menos y posiblemente sea defintiivo porque vine a vivir en Chile porque como te dije mi esposo es Chileno, lo cual me llena de mucha tristeza. Vine en el 94. (C,pgl.p1)

\subsection{Enfrentadas al espejo del cambio}

La adaptación como tal no significa la transformación inmediata y total de las características fundamentales de las personas. Es decir, siguiendo a Munizaga, la gente necesita un apoyo, un puente a través de grupos formales o informales, que le orienten en el proceso de inserción y una vez allí se cumple de manera lenta y paulatina la asimilación de las distintas formas y condicionamientos sociales y culturales posibles.

Al hablar de cambio cultural en las mujeres migrantes habrá que determinar primero si éste sucede a nivel de su marco de representaciones, de sus sistemas de relación, de sus esferas de vida, (social, económica y cultural). Bastide llama aculturación formal a un proceso lento, lleno de ajustes y conflictos entre representaciones colectivas, valores y sentimientos de pertenencia, donde lo que se produce es una transformación en la forma de sentir y aprender de esa persona; es aquí donde radica la diferencia fundamental respecto de la asimilación y la adaptación ya que estos dos conceptos se relacionan con la posibilidad de unificar contenidos culturales mediante un sagaz equilibrio de los contrarios o la simple adhesión a un sistema único de valores. "De vez en cuando hago comida chilena que aunque no sé mucho, me bato porque a mi marido le gusta la comida chilena(B. Pg6.p32)

De tal manera que se está hablando de hechos sicológicos vividos o experiencias que luchan por ocupar un espacio.

\section{El ojo en las costumbres, las rutinas y los hábitos}

Una vez que se ha podido superar las primeras barreras culturales relacionadas con el espacio público, se ha de producir una paulatina transformación en la esfera de lo privado 
respecto al uso de determinadas recetas o formas de hacer las cosas, su habitualización para producir una rutina y finalmente la costumbre de operar de una determinada forma, entre las otras formas conocidas. Al parecer es ahí donde se reportan cambios muy significativos en relación a cómo se disponen las cosas y el porqué de esto. Un ejemplo podría ser la preparación de los alimentos, el acondicionamiento del espacio privado, etc.

"Cuando estoy en mi cuarto trató de que se vea bonito a pesar de que sea chiquito, no sé que se vea ordenado porque antes yo era muy desordenada y no sabía lo que era tener una casa; a veces llegaban mis amigos y les invitaba a comer cualquier cosa> en cambio ahora ya tengo una idea, por ejemplo si van a llegar, estoy preocupada de que se vea bien mi pieza, yo adorno, o sea bonit”o (A.pg6.p38)

La aculturación formal no está indicando la permanencia de una mentalidad con relación a otra o la inmovilidad de aquella sino que busca entender y relacionar aspectos sociológicos con otros psicológicos individuales

"Más o menos, al principio más que ahora. Cuando nos reunimos con amigos ecuatorianos tratamos de preparar cosas de allá y compartimos mucho pero en la vida diaria yo ya no pienso mucho y he ido asimilando costumbres de acá especialmente porque tienes nanas de acá que tienen su forma de hacer las cosas y uno sin darse cuenta va adaptando y acostumbrándose a otra forma de vivir" (C,pg9.p32)

Siendo ésta la diferencia más válida entre la aculturación material y la aculturación formal; tratándose de un concepto neutro y muy operativo. Existirían dos niveles en los cuales pesquisar el impacto de la migración, a saber: uno material y otro psicológico. Sin embargo en la realidad se hace muy difícil diferenciar estos dos planos ya que no queda muy claro cuando comienza lo uno y termina lo otro, si al final del segundo hay un cambio de mentalidad, cuántas y cuáles son las mezclas que se producen y cuáles son las rupturas y a qué nivel se producen si en la afectividad o en el pensamiento. "Yo le digo aquí en mi casa estoy yo y mi manera de ser y por último es Ecuador, allá afuera es Chile y cuando estamos allí serán otras cosas. Por lo tanto él tiene que asumir reglas.(B.pg7. p36)

La pregunta que surge entonces es ¿Cómo se reconocen estos niveles en un individuo si se sabe de antemano que toda forma es inconsciente? Bastide establece la necesidad de reconstruir los procesos de desorganización y de reorganización de antiguas formas de 
percepción, de memoria, de afectividad y pensamiento; esto quiere decir que el pasaje de una forma a otra no ocurre bruscamente como en línea recta. "A mí me gusta cocinar los Domingos comida ecuatoriana, pero como no hay siempre las cosas a mano se ponen otras cosas y queda una mezcla muy rica” (B,pg4,p31)

\section{El ojo de lo Primario}

Una vez que se ha superado el proceso de inserción y asimilación cultural, las personas que migran necesitan reconstruir sus mapas personales, interiorizarse del hecho de que no están en su medio y que una vez atravesado este paso se han producido algunos cambios relacionados con la familia, lo laboral, las expectativas económicas y sentimentales, los afectos, etc.

La crisis respecto a la esfera familiar es una de las primeras transformaciones que se suceden puesto que esto tiene que ver con la actualización del tema de la pareja, de la situación de ellas respecto a sus hijos o a sus padres. Entre las entrevistadas se evidencia una diversidad de situaciones respecto al tema; Se observan matrimonios de parejas nacionales o biculturales que están viviendo procesos de fortalecimiento o fracaso Ahora es el momento en que se verá si él quiere seguir conmigo porque no tiene trabajo seguro él, ni yo y podría abrirse pero aquí se verá...”(B,pg4.p36

Se observan matrimonios que han venido desde allá y se han disuelto acá, personas que habiendo estado casadas en su país de origen, han constituido nuevas uniones y parejas transitorias. " Siento que ya no soy más su pareja, me he alejado porque al principio extrañaba pero ahora no. Ahora tengo otro chico acá y me siento bien con él, no hay trabas, ni hijos, ni nada (J,pg6,p26)

Toda esta gama de posibilidades se relaciona con algo capital que es la profunda sensación de soledad y aislamiento para lo cual se sienten empujados a relacionarse con distintos grupos sociales; ya que la circunstancia que marca la vida del migrante en el extranjero es la constante sensación de no pertenencia, reflejada en los problemas cotidianos que les 
aquejan a ellas, sus parejas, hijos o amistades. Situación que se ve revitalizada, a partir de la reconstrucción de sentidos como requisito indispensable para manejar las relaciones interpersonales y las presiones sicológicas.

Al parecer, quienes migran y deciden quedarse en Chile, junto a su familia constituida son las que mejor elaboran el proceso de asimilación debido principalmente a que deben reedificar permanentemente el sentido de pertenencia especialmente para sus hijos y para la estabilidad necesaria cuando se vive fuera; sin embargo, también se puede establecer que es un aspecto que nunca termina por resolverse puesto que se participa de una sociedad siempre en condición de extranjero. Bueno, ahora ya es diferente cuando decidimos que nos quedábamos porque ahora estoy con mis hijos, con mi marido y es muy diferente la vida porque estoy con mi familia.’(B,pg4,p39)

En palabras de Chambers hablar del desarraigo es hablar de la memoria, el olvido, de lo incompleto; situación que también significa un cambio para todo aquel que migra y que está condicionado por la ausencia de un sustrato material que facilite el acoplamiento de los recuerdos; de manera que el ir y volver es palpar un lenguaje que está atravesado por la pérdida

Mi familia claro, es un aliciente para mí verlos y pasar todo el tiempo que visitando familia, que viendo amigos, que yendo de aquí para allá y sobretodo comiendo mucho cebiche y patacones y cerveza uhmmm (C,pg8,p51

\section{La mirada de las expectativas}

En la esfera de lo laboral, profesional, se obtienen interesantes hallazgos debido a que para muchas, éste es el trasfondo de su traslado y una vez aquí, insertadas laboralmente y obteniendo un salario importante en relación a lo que ganaban en Ecuador, se dan cuenta de un cambio en torno a sus expectativas de vida, la valoración del dinero, a la necesidad de superación educacional; ya que ésta circunstancia les hace participar en una realidad distinta a la su país de origen ya que se está dentro de un contexto de fuerte competencia, de altos niveles de exigencia y productividad. Este hecho es un factor positivo dentro de la valoración del país de acogida y de su propia experiencia. Después de mi postgrado y de 
encontrar un mejor trabajo tuve la gratísima experiencia de sentirme competente y bien conmigo misma, que aunque las dificultades y el trabajo son duros, la compensación por ello, son buenas condiciones de existencia y expectativas futuras ( $k, p g 4, p 31)$

En relación a las expectativas educacionales, se observa un cambio en relación a la valoración y la contingencia por obtener un mayor nivel educacional, que en el caso de las mujeres con un bajo nivel de escolaridad; es un desafío que ellas se han propuesto para sus hijos "Sé que trabajando puedo tener lo que yo quiera y lo mismo a mis hijos que es el darles la educación que yo no he podido lograr y por eso me preocupo mucho de inculcarles que sean responsables, ordenados y que hagan bien las cosas” (B,pg3,p26) Detrás de la fuerte valoración del trabajo y la educación se encuentran implícitos valores muy actuales en la sociedad chilena.

El dinero, la participación en el consumo y la imagen son gatilladores de una sensación de bienestar y de compensación de los sacrificios realizados. Para algunas de las entrevistadas esto es muy evidente al interrogarlas respecto a su valoración respecto de lo que han vivido, respecto a su familia de origen y su familia constituida, su identidad, el valor del dinero, etc.

"Ahora es mi propio esfuerzo, mi propia plata, no tengo que estar pidiendo a nadie. Si yo quiero irme de viaje me voy, si deseo comprarme algo, me lo compro, si es de ayudar a alguien, lo hago porque no tengo que estar pidiendo a mi papá por eso me siento independiente porque nunca me ha gustado depender de nadie(A.pg5.p31)

El tema del dinero es algo que está presente en la mayoría de las preocupaciones y logros que han obtenido al venir a Chile, no sólo por el hecho de que han logrado solucionar con ello problemas de desempleo, falta de expectativas o de subsistencia sino por el hecho de que sienten la satisfacción del manejo del dinero y la posibilidad de sentirse independientes. "En términos de plata sí también porque yo he mandado, tengo acá, he mandado para mis niños, para mi mamá; bueno, en esto me siento realizada, porque mando un poco allá y otro poco me queda para mis salidas para lo mío para comprarme lo que me hace falta(J;pg5,p21) 


\section{Mi ojo interno}

Los cambios a nivel personal pueden verse reflejados en cambios de conducta o actitudinales, cambios valóricos, cambios en la indumentaria y la forma de ordenar la rutina

He cambiado harto, lo mismo en la forma de ser de antes, yo era muy tímida, más limitada mi conversación con mis amigos, era lo necesario nada más Yo he cambiado mucho acá no salía con los amigos; en cambio acá salgo con amigos, comparto más con ellos(J,pg4,p17)

Se evidencia también un cambio de roles, situación que se relaciona de manera muy clara en relación con el manejo y destino del dinero, cambio de roles dentro del grupo familiar, una participación más directa en las decisiones, en el modo cómo se educarán a los hijos y sobretodo en relación a la forma en que se condicionan los afectos.

El se preocupa mucho por mis hijos, Ahora que esta sin trabajo hace la comida para todos, es una ayuda total, entonces uno no se preocupa porque todo marcha bien. Es como un cambio de roles. (B.pg6. p31)

Es de anotar que este cambio de roles también se observa en las familias que debiendo insertarse laboralmente el padre y la madre, los hijos deben suplir las funciones del cuidado a los más pequeños o el caso de niños que se han quedado en Ecuador al cuidado de una hermana o un familiar

Sin embargo también se hace visible en relación a las relaciones interpersonales, una asimilación de patrones y pautas de la sociedad chilena en relación con la deconfianza, el permanente "chaqueteo" "Lo que si no me gusta del chileno es que trata a toda costa de hacerle creer a uno, de tomarle el pelo, hablan mal de todo el mundo y muchos de mis amigos son igual ahora. (A, pg6,p35)

La necesidad de entrar dentro del consumo y la sensación de vivir de la apariencia. Es otro de los hallazgos entre las entrevistadas, especialmente aquellas con bajo nivel de educación donde la imagen se transforma en un ingrediente dentro de las relaciones entre coterráneos, situación que para ellas están sobreentendidas tratándose de relaciones circunstanciales y en permanente tránsito. 
Mis amigos dicen que han venido a conocer y que tienen experiencia y dicen que hay que pasarla bien, que hay una sola vida que se vive una sola vez, se gastan la plata en aparentar lo que no tienen; claro que es así pero hay que pensar en el futuro, hay que tratar de ahorrar"'(A,pg4,p37)

Los obstáculos que deben atravesar especialmente en relación a los afectos y las relaciones de pareja no son siempre fáciles de superar; por lo que, muchas veces las consecuencias de los cambios producen estados de tensión y depresión “Incluso me dio depresión, por todo lo que me pasó, el doctor me dijo que era demasiado estrés(J,pg5.p25)

Algunas han sido expuestas a situaciones límite especialmente aquellas mujeres que han venido sin sus familias y el cambio ha sido demasiado abrupto, adaptándose a circunstancias siempre cambiantes y donde prima un estado de desconfianza

Creo que a las personas que conozco y a mi misma es duro decir que los chicos sólo le toman de paso, le utilizan, le toman para el momento, ellos no quieren algo estable porque dicen ellos que todos estamos emigrando, todos queremos hacer algo y hacerse de alguien no está en sus planes; ellos quieren pasarla bien y nada más.. Los chicos chilenos no son recomendables porque uno es emigrante es y por eso le gusta la vida alegre, le gusta pinchar y pasar y acá jamás le toman en serio. (A.pg5.p34)

De tal manera que al hablar de tránsito se supone que existirían algunos efectos como “costos sociales" "desorientación personal" "deterioro moral”. A mí ya no importa tener sexo con cualquiera solo hay que cuidarse. podría hacer lo que me plazca, si no funciono, bueno, ahí te quedas y tomo otro chico. (A.pg1.p6)

\subsection{En torno a la identidad}

La identidad para el migrante es un aspecto que solamente comienza a aparecer una vez se ha cruzado una frontera geográfica, ya que siguiendo a Said(1990) es un punto donde se cruzan las fronteras, donde habita la alteridad siempre en tránsito; suponiendo de antemano que la condición del extranjero es el deshabitar un espacio físico, social y cultural para transitar y /o morar en otro; como bien lo describe una de las mujeres entrevistadas creo que es una experiencia algo traumática ya que te enfrentas a muchas cosas muy profundas, es un proceso de desarraigarse de un espacio geográfico, social y 
humano para meterse en otro. cúanto tiene que cambiar, desde el ruido de las cosas, la alimentación, la necesidad de abrigo, y no hablemos de otras cosas más complejas Eso es muy duro y a partir de alli es que empiezas a echar de menos todo, tus hermanos, tus amigos, tus padres, los lugares donde creciste. Ahí es que tu identidad como persona se enmarca más, te sientes construida sobre la base de otras sensaciones y experiencias como es el tema de la familia, los lazos, la calidez. $\operatorname{etc}($ C.,pg5.p31)

Frente a las interrogantes sobre los mecanismos, elementos y valoración de su propia cultura por oposición a $\mathbf{b}$ chilena, las respuestas apuntan a una diversidad de opiniones y criterios que integran al concepto cultura. Siendo la identidad una categoría abstracta que puede ser distinguida a partir de mecanismos como la etnicidad, el género, la clase, la raza y otros sistemas o aspectos culturales, económicos y sociales.

Debido a la dificultad de integrar muchas de las expresiones y sentidos en relación con los aspectos que se conjugan con la identidad; el mecanismo de la "etnicidad" parece abarcar gran parte de ellos porque se relaciona con la identidad de grupo, que no está completamente precisada pero que sin embargo liga de manera muy fuerte a sus miembros a través de la participación permanente de un idioma, tradiciones, valores.. " Para mí vivir en otro país es como estar en dos mundos, es muy difícil porque se siente uno contenta y ve lo que es la familia, que le aceptan todo, lo sencillo, en cambio allá es la rectitud, la pulcritud y elegancia de las cosas.(B, pg3, p17)

Si se atiende al hecho de que la "etnicidad" es una categoría subjetiva que integra a un grupo sobre la base de elementos culturales compartidos, entonces se podría establecer que es también un proceso dinámico dependiendo del marco de pertenencia, participación, el grado de armonía existente, la empatía y sobretodo del entorno cultural en que se encuentran. Como se mencionó anteriormente, las respuestas son muy variadas respecto al tema de la identidad. La mayoría de las entrevistadas sean parejas ecuatorianas o mujeres solas establecen como fundamental la filiación a un grupo de coterráneos y por lo tanto la innumerable variedad de prácticas y costumbres compartidas; sin embargo, al parecer respecto de la imagen de sí mismos en relación al grupo es ambigua ya que por un lado gran parte de su experiencia migratoria va a estar atravesada por la relación al interior de estos grupos, Ahí se conocen, emprenden amistades, establecen sentidos, valoración, se 
relacionan afectiva y sexualmente pero en el largo plazo son relaciones frágiles y transitorias incapaces de desarmar el nudo de la inestabilidad y la desconfianza. Son afectos transitorios, superficiales.(B, pg4. P20)

Confío, digamos que en gente de mí mismo lugar, aunque a veces también le defraudan porque se tiene mucha envidia entre unos y otros y la verdad es que amigas, amigas no, como uno está en un país distinto, no sé sabe si son buenas personas, sus costumbres tienen, la forma de pensar y a veces uno se equivoca y le dan terror de confiar en las personas (A.pg5.p33)

Al parecer, Migración e identidad serían términos aparentemente contrapuestos ya que suponen una confrontación permanente con la inestabilidad. Exige que el yo cultural se desplace al "yo" de los otros y el consiguiente debilitamiento e incertidumbre entre los pensamientos y las acciones. Retomando los conceptos trabajados por Bastide sobre aculturación formal y material podemos suponer que las personas que migran están en un primer momento confrontadas por sus acciones y la necesidad de organizar una rutina y luego el movimiento sigue y el salto se apresura a desentrañar nudos en el pensamiento, la emoción o la afectividad que están en un plano más profundo y de largo soplo donde finalmente se va rearmando identidad.La rutina por fin era una rutina y ya no sentía ese vacío que sentía al principio pero tarde cerca de 2 años en esto. (C,pg3,p31)

El primer peldaño de este encuentro con uno y con la alteridad es habitar el desarraigo donde se abandonan las viejas certezas para dar paso a un resultado incierto hecho de encuentros en donde el tiempo se vuelve inestable y siempre sujeto a la re-interpretación (imagen subjetivada) sobre el "microtejido de todos nosotros",

"Creo que hay muchas cosas que se relacionan con mi historia, y de la muchos de mis amigos ecuatorianos, una es mi familia y los valores con los que me formaron y lo otro es todo lo aprendido allá como cultura que nos sirve acá porque si eso no estuviera, no podríamos hablar de nada" (K,pg3,p34)

Por lo tanto estamos frente a un yo específico, porque estamos hablando de un tiempo compartido y también muy limitado. Sin embargo, no implica una evasión del compromiso sino que es un espacio lleno de interrogantes, diálogos y de miradas que se transforman en 
un lenguaje del silencio. Según Chambers este lenguaje induce a la mirada humilde y curiosa del extranjero.

Al repasar un tiempo y el espacio dentro de una cultura, un lenguaje, una costumbre, la institucionalización es también por así decirlo un replantamiento respecto de hacia donde se va, por donde y los límites de estas mismas categorías. Al abordar el tema de las expectativas, éste incluye una recreación de los aspectos más sobresalientes en relación a una definición del sí mismo, de la cultura que uno tiene y los horizontes por los cuales uno camina. De esta manera, dicha valoración también imprime una carga positiva o negativa en relación al entorno.

Cultura o sea de la familia o sea cómo que no les importa la familia, no están ni alli con ellos, ni los padres, viven su vida sin importarles el resto pero en cambio uno en eso es diferente tiene una forma distinta de pensar, tiene una cultura diferente, digamos uno es más apegado a la familia, a su país, si uno está acá es por necesidad de trabajar, para un mejor futuro y tener algo y eso pienso yo. (A,pg4.p38)

El sentido del desarraigo o la no participación plena en su cultura da origen a la percepción de que uno vive entre dos mundos, entre un pasado perdido y un presente no integrado. Quizá sea esta metáfora la condición post- moderna en muchas ciudades latinoamericanas.

"Creo que a la larga va a afectar mucho porque yo tengo que dividirme siempre y ver que mi realidad se construye sobre la base de cómo esté mi familia aquí y mi propia historia "(C,pg4,p35)

Siempre me hacía falta y me hizo falta mi país, trataba de irme, pero al mismo tiempo me daba pena dejar todo lo que tenía (B,pg3,p19)

La migración irrumpe y pone de relieve temas muy atingentes a la modernidad; la mación el lenguaje y su sentido de identidad; la metropolí, el serntido de la homogeneidad síquica y cultural. Para Chambers nuestro sentido del conocimiento, de la lengua y la identidad no pueden borrarse al atravesar una frontera ya que aquello legado como historia, lenguaje, tradición, no se destruye sino que se desplaza, se reescribe, se reencauza a través de un espacio fundamental en cada uno de los individuos que es el "YO" síquico que se forma y se reforma en este movimiento constante en el mundo. De modo que la identidad se forma en el movimiento. 
Es decir, que los mecanismos por los cuales se fija la identidad en un espacio y un tiempo de tránsito dependen en gran medida de la capacidad emocional y síquica incorporados en el sujeto, de su capacidad de adaptación y de su sentido de sobrevivencia. En este viaje abierto e incompleto se va construyendo identidad pero ésta no es fija ni tiene un destino final.

Existe un sentido del ser y de la pertenencia que incluye no sólo la etnicidad y la raza, sino también la sexualidad, el género, el lenguaje, la nación y el viajede esta manera gran parte de la reflexión contemporánea trabaja sobre estas categorías universales como algo de minorías o un objeto dentro de otros objetos.

Un concepto importante que ha sido descrito con mucho detalle en la mayoría de las entrevistadas es la sensación de ser objeto de discriminación y que esta estrechamente relacionado con la identidad; La valoración positiva o negativa entre un grupo dominante y otro minoritario va a depender de una serie de mecanismos presentes en el concepto de reciprocidad, es decir, que en las actitudes mutuas habría un proceso de categorización donde se encubren ciertos prejuicios o atributos negativos respecto de la migración fronteriza sea ecuatoriana o peruana.

El tipo de relación, la intensidad, la empatía entre la sociedad de acogida y las inmigrantes va a depender de la carga negativa o positiva que se tenga respecto del grupo en cuestión. La confrontación con extraños "otros” implica que habrá que marcarse bien los límites, las fronteras y los territorios entre los unos y los otros.

"Con los chilenos, ninguna conversación profunda. No nunca me he relacionado mucho, ni muy bien con ellos, nunca a las casas de ellos, ni compartir, a veces irnos a algún bar, una discoteque a tomar alguna cosa pero nada más(A,pg5.p19)

A partir de ahí el conocimiento mutuo dependerá a confirmación de ciertos estereotipos y sus significados. Algunos de los aspectos más claramente señalados han sido la prepotencia, el egoísmo, el individualismo, la superficialidad respecto de los chilenos.

Eh, tengo amigos chilenos pocos, casi no sé, me simpatizan de lejitos no más, no me inspiran confianza, chilenos hay muchos en Ecuador y nadie les dice nada, o sea el hecho de que uno es inmigrante como que le querrían menospreciar y se querían 
hacer más que uno pero también he tenido amigas chilenas buenas gentes pero hace mucho tiempo que no sé nada de ellas.(A.pg5.p32)

Las migrantes están sometidas cada vez más a redes de muy compleja negociación e interacción cultural donde por ejemplo, ellas están sujetas a la doble articulación en discursos sobre la diferencia y el patriarcado o machismo muy latente en Latinoamérica. Esto provoca que la intención de negociar su personalidad independiente en la vida cotidiana moderna se vuelva por un lado muy estimulante estudiar y muy contradictoria por otro a partir de las rupturas que en ellas se producen.

Es decir, a ratos siento que solamente tengo cabida siempre y cuando esté casada con un chileno, ese es mi salvoconducto. Yo me puedo mover tranquila sintiéndome más ligera de cargas porque al haberme casado con él, la gente no te excluye tanto porque en apariencia ya no soy completamente extranjera pero y, me pregunto porqué siendo uno extranjero, no es aceptado?

Respecto a la discriminación de que son objeto los migrantes, uno de las explicaciones quizá está en lo que Benjamin y Wittgenstein llaman el estar dentro del lenguaje desde el cual se construye el mundo y la alteridad supone una extensión de esta transformándose en un ajuste muy complejo ya que supone encontranos con historias, culturas y experiencias no conocidas y por lo tantosurge un encuentro cragado de incertidumbre y miedo debido a que situarse en el lenguaje es también admitir un yo de nuestar razón y conocimiento y teme y margina al otro por realizar su especificidad y sus límites y trata de reducirlo a una forma de desigualdad y desintedidad. Sin embargo como manifiesta Chambers situarse en el límite es estar expuesto a la apertura donde es posible escuchar las diferencias

Para Said, es posible que una perspectiva auténticamente migrante, se funde en la intuición de que la oposición entre el aquí y el allá sea en sí misma una construcción cultural, una consecuencia del hecho de pensar en términos de categorías fijas definidas en forma de oposición; para lo cual se podría considerar al mvimiento no como un incómodo intervalo entre el punto de partida y de llegada establecidos, sino como un modo de ser en el mundo, entonces la cuestión no estaría en llegar, sino en cómo moverse e identificar los movimientos convergentes y divergentes, y el desafío consisitría en cómo consignar dichos acontecimientos para otorgarles un valor históricos y social.(Carter;1992:101) 
Para este autor hay un vicio con el que se trabaja en la teoría sobre migración debido a que se asume el "eterno retorno" y al intentar comprender esta suspensión, nos encontramos con dos distinciones; una el Ethos que significa colocarse en otro lugar (acontecimiento) y topos como lugar definido (signo) de lo cual surge una permentente acción recíproca; sin embargo se podría pensar que entre estas dos categorías está el movimiento entre un aquí y un allá donde se experiemnta la posibilidad de la promesa y por b tanto es éste eldestino de dirigirse al otro y se emprende un viaje donde se va reconociendo la distancia, la diferencia que hace posible la experienciagrupo social cuyos miembros consideren la observancia de estas reglas como un requisito para pertenecer.

\subsection{Identidad de Género}

Qué significado tiene para las mujeres migrantes ecuatorianas el desarraigo y la construcción de una nueva identidad?

No sé, Chile me ha servido bastante, quizá tener la experiencia, madurar un poco porque antes era inmadura. Sé lo que me cuesta ganar el dinero para el día de mañana yo irme a mí y no depender de nadie pero toda esta experiencia me va servir allá, en mi casa, con mis hijos, tener una costumbre diferente, una forma de pensar diferente. Quizá yo antes no valoraba nada, nunca me gustó estudiar, ni tener mucha cultura pero quiero que mis hijos tengan una buena educación, enseñare todo, que tengan una distinta manera de pensar (A.pg7.p40).

Si bien, el tema desarrollado se centra en el proceso migratorio de mujeres ecuatorianas cuyo universo corresponde a distintas unidades muestrales que se diferencian en rangos de edad, con familia constituida o no, con distintos niveles de socio-económicos y de escolaridad, con distintos grados de experiencia laboral, etc. Al elaborar el análisis sobre la identidad de género en general, se ha de destacar un tipo de emigración femenina que está segmentada como mujeres trabajadoras no calificadas, o aquellas que habiendo obtenido un título se han visto forzadas a trabajar en otras actividades no correspondientes con su profesión o capacitación técnica. Sin embargo, ésta es solo una manera de abordar el tema de la identidad de género en las mujeres emigrantes ya que, los rasgos que se evidencian aquí parecen corresponder a los del "grupo doméstico" que se ha internacionalizado frente a la dinámica de mano de obra en países con mayores niveles de desarrollo. 
Quizá luego quiero irme más lejos y porque dicen ellas que ellas tienen marido e hijos en Ecuador y ellas gastan y porque yo no lo hago, si vivo sola, no tengo a quien mantener, debo gastar y vestirme bien debo darme lujos, de ir a muchos lados, de viajar, en cambio ellas tienen que mandar plata todos los meses y se dan gustos pero yo digo el hecho de que yo no tengo nadie a quien mantener, no significa que yo tenga la necesidad de gastarme toda la plata que me cuesta tanto ganarme en otro país, porque ayudo a mis papás un poco y otro poco me quedo yo.(A.pg4.p16)

El análisis de identidad de género en el contexto de la transnacionalización de las unidades domésticas será abordado en tres ejes:

- Los factores explicativos de género como gatilladores de migración femenina y por consecuencia, el fortalecimiento de grupos domésticos transnacionales

- Los cambios producidos en la división sexual del trabajo

- Cambios en el sistema de poder y autoridad.

La característica más sobresaliente de esta tipo migración en Chile es la ubicación laboral dentro del servicio doméstico con la modalidad de internamiento, que tiene su explicación en la rapidez con la que consiguen empleo, no requieren gastos de instalación y pueden contar con la totalidad de su sueldo a final de mes para ser enviado a la familia.

Aunque en un primer momento el hecho de emigrar se constituyó como una alternativa tendiente a solucionar dificultades de subsistencia, debido a que la mayoría de ellas al momento de partir habían constituido ya una familia y su ausencia se veía como un proyecto temporal; la evidencia da cuenta de que la realidad ha hecho que este proceso se alargue mucho más de lo esperado y más bien tendería a ir en aumento, especialmente lo referido a este tipo de migración. Es de anotar también que muchos de los testimonios dan cuenta de un cambio en los esquemas de producción y reproducción de las mujeres emigrantes y de sus hogares. Sus indicadores serían la ruptura de las unidades familiares, el cambio de roles; en algunos casos, la perpetuación de la emigración de las mujeres que junto a sus hijas alimentan el proceso; la disminución y desaparición de estrategias económicas compartidas y por lo tanto la conformación de una nueva unidad doméstica en 
el contexto receptor, a pesar de seguir manteniendo la relación a través de ayudas económicas puntuales, cartas, llamadas telefónicas, viajes, etc.

Siento que me he alejado de él porque al principio sí extrañaba pero ahora no. Como que en el sentido de que me haya alejado de él a pesar de que nos escribimos, nos llamamos pero yo siento que me alejado de 'él. La frecuencia con la que nos llamamos es muy poca, antes si era más pero ahora ya es casi nada. Antes estaba con los niños pero ahora ha tenido un problema con mi hermano y ha salido de la casa de mi papá y no sé que problema es y nadie me dice que ha pasado.(J,pg6,p26)

\section{El Mágico poder que da el dinero}

El dinero en cuanto valor de cambio aparece como esencial dentro de la migración de mujeres ecuatorianas a Chile ya que por un lado éste es un reflejo de la posibilidad de sentirse productivas en términos monetarios ya sea porque hay un factor económico detrás de muchas de ellas, relacionado con la crisis de este país o porque hay un factor de género, que se relaciona con la dispar disponibilidad de dinero existente entre hombres y mujeres dentro de los hogares.Sí porque, digo que sí porque estoy trabajando, no estoy dependiendo de nadie, tengo mi propio dinero. (A,pg7.p25)

El esquema tradicional es que muchas de ellas no aportaban remunerativamente o lo hacían compartidamente con sus parejas en trabajos generalmente informales antes de emigrar y una vez aquí mo quieren renunciar a su capacidad generadora de ingresos, ni renunciar a la posibilidad de ir y venir al país en estos momentos de crisis, por lo tanto esta situación es valorada como muy positiva. "Antes yo era dependiente y me sentía como un mueble, porque el trabajo y el dinero a usted le hace sentir útil, usted trabaja se siente bien, sabe que va a tener su propio diner.o Sin trabajo uno sería un mueble más en la casa, una persona inútil, que toda la gente le estaría mirando mal como esa mantenida, buena para nada.(A,pg8.p30)

Este ingreso tiene una significación muy especial porque de manera muy visible garantiza la reproducción del hogar hacia un nivel de vida que se estima deseable. Sin embargo, el poder que da el dinero no solamente parece tener relación con la posibilidad para entrar en el consumo y garantizar la reproducción material de un grupo familiar sino que también tiene una valoración muy importante relacionada con la capacidad de independendizarse 
económicamente del varón proveedor; sea éste el padre de los hijos, el propio padre, o la pareja.

Mi experiencia bonita es sentir que ahí está toda mi vida porque nunca he vuelto a vivir una vida más bonita que vivir allí, me sentía contenta por que mandaba plata yo me sentí libre, haciendo lo que quería y ganando lo que quería. Era libre. (B. Pg3. P15)

Esta situación se hace muy notoria especialmente en países como Ecuador, donde todavía la división sexual del trabajo está aún muy segmentada especialmente en los estratos socioeconómicos más bajos y siguen manteniéndose los mismos esquemas tradicionales "De que la mujer está en la casa y el hombre en la calle produciendo" Sin embargo, esto ha ido cambiando en parte por las crisis extremas que han sufrido países de la región donde la mujer ha tenido que salir a trabajar para aumentar el ingreso del grupo familiar y la función del hombre como mantenedor de la familia está en crisis.

Hay el sentimiento de sentirse menos humilladas o con su autoestima alta después de la primera experiencia de migrar al probar lo que significa tener dinero para ella y su familia.

Y como yo misma dándome las fuerzas y de hacer lo mismo que hacen los hombres y trataba de hacer ver a la gente que yo era capaz o que yo mismo me dé cuenta de que era capaz de todo porque la misma persona que él dejó o que maltrató y quizás quise demostrarle a él todo lo nuevo en mí. (B. Pg4. P21)

Dada en su respectivo país, la inexistencia de un mercado de trabajo que no ofrece las expectativas de remuneración para la reproducción familiar; esto ha fomentado el crecimiento de la migración femenina hacia destinos con mayor diferencia salarial. El aumento del ingreso en el hogar ha sido mucho más valorado que su sola presencia al interior del hogar y por tanto, se evidencia un cambio en los patrones de consumo debido a una mayor adquisición monetaria. En general el envío de dinero se destina a la alimentación, ropa y educación de los niños..

Esta situación se vuelve indispensable y necesaria para las mujeres emigrantes que contradictoriamente tienen la sensación de recompensar materialmente por su ausencia al 
querer satisfacer todos los miembros del grupo doméstico. Como consecuencia, la posibilidad de ahorro se hace difícil.

Por otro lado, La emigración de la mujer supone la pérdida de su valor productivo dentro del grupo doméstico y de un bien para la sociedad entera ya sea a través de su pequeño aporte con trabajos informales o principalmente, por el reacondicionamiento de las funciones y estructura al interior de los grupos domésticos ya que en algunos de los casos, el ahorro de las tareas tradicionalmente no remuneradas que venían realizando estas mujeres, ahora lo están realizando otras personas y muchas veces a cambio de un dinero.

Esta reorganización se refleja tanto en la distribución de tareas designados a cada uno de los miembros como en la toma de decisiones que afectan a esta.

Ella está de mamá de todos porque ella es la que se organiza con el dinero que yo le mando y distribuye esto es para esto, esto, esto paga la luz, teléfono, agua, todo, todo y va al colegio, va a las reuniones de sus hermanos y yo esta vez que me he ido muy bien están sus hermanos porque en los estudios están bien (R.pg4.p21)

Su salida supone la imposibilidad de velar por el mantenimiento social y material que tradicionalmente venían haciendo. El envío de remesas por parte de las mujeres emigrantes va a ser un factor determinante para que se abandonen antiguas y tradicionales estrategias productivas convirtiéndose en proveedoras económicas de sus hoga res dado a través de la posibilidad de asegurar el costo de la canasta familiar básica y de la continuidad de los envíos.

Sin embargo, el hecho de emplearse en actividades de trabajo doméstico o actividades informales, les impide obtener capacitación o adquirir mejores y mayores habilidades para integrarlas en sus comunidades de origen una vez que retornan. Una cosa que es muy es el tema de la educación de los hijos, que se ve como óptimo respecto a la realidad educacional en sus países de origen.

Pienso que mis hijos ya salgan a estudiar a otro lado, ya no quiero que mis hijos estén ahí mismo. En ese sentido sí, las pienso hacer. Por ejemplo, ya ahora sé que mis hijos no me pueden comer cualquier cosa porque ahora ya me doy cuenta que está mal pero a mí me criaron así pero ahora sé que eso está mal, no es que ellos elijan las comidas sino que uno debe elegirla (J,pg3.p21) 
Existe una valoración positiva en cuanto a la alimentación del país de origen, La tranquilidad del trabajo doméstico en sus hogares frente a la dureza del trabajo doméstico en los que trabajan con régimen interno, Los patrones para educar a menores y jóvenes valorándose como positivo en su país la unidad familiar y las jerarquías, ya que en Chile se ve como negativo la falta de respeto especialmente a los ancianos y finalmente En Chile, la calidad de vida dada por el acceso a la tecnología , los sitios para distracción y ocio y la cantidad de cosas que consumir.

Cultura o sea de la familia o sea cómo que no les importa la familia, no están ni allí con ellos, ni los padres, viven su vida sin importarles el resto.(A.pg3.p12)

Lo único que cuenta es el trabajo físico que no es igual que con otras profesiones como médicos, abogados, ingenieros pero el resto no valen nada. Que aquí uno viene a trabajar en casa y lo que le manden y con buena cara.(A,pg3.p21)

\section{La división sexual del trabajo dentro de los grupos domésticos transnacionales}

La reproducción material ha podido garantizarse utilizando la red de parentesco, pero se evidencia un descuido en la calidad del cuidado y reproducción material de los hijos especialmente en la alimentación, el cuidado de la ropa, el aseo del hogar; Además, las tareas relacionadas con la reproducción social como serían espacios de socialización y educación y la función afectiva se ve afectada porque ellas son un elemento centralizador de las relaciones afectivas en torno a la unidad del vínculo familiar.

\section{La dinámica interna: el sistema de poder y autoridad}

El poder ha sido entendido como la capacidad para incidir sobre la vida de los otros.Entre los grupos domésticos transnacionales se evidencian algunos cambios relacionados con la toma de decisiones especialmente en relación con el gasto de los ingresos, el control sobre la sexualidad de las mujeres.

Respecto a los dos primeros aspectos, se ha establecido un cambio porque han invertido el orden establecido especialmente porque el ingreso que ellas reciben muchas veces es mayor a la que el hombre recibe y por otro lado porque al emigrar los hombres pierden el control 
sobre la sexualidad de éstas. En cuanto al control sobre los gastos se evidencia un cambio ya que este se ha desplazado hacia las mujeres y por lo tanto le concede mayor poder ya que tradicionalmente éste era una forma de dominio para ella ya que siendo él quien garantizaba el destino y el control del dinero, ella estaba sujeta a estas reglas. Se puede concluir que el hecho de que mujeres que nunca antes habían recibido un salario como aquellas que sí, la emigración significó un cambio importante respecto del poder de negociación en sus relaciones de pareja y dentro del hogar; especialmente sobre la cantidad de dinero enviado y del destino de éste.

Bueno, uno si se compra las cosas que uno quiere, ya no necesita estar pidiendo las cosas que uno quiere. Me daba mi papá o mi marido pero acá ya uno se siente que tiene y que se compra lo que a uno le gusta y ya po allá había que limitarse, en cambio acá no. Más carito y a uno le gusta eso y se los compra(J,pg2,p18)

\section{EI Control de la sexualidad de la mujer}

El control de la sexualidad se refiere a la capacidad de decisión sobre la práctica de las relaciones sexuales; dicho control impone restricciones respecto de las actividades del orden público. Muchas de ellas dan cuentan de un cambio en relación al papel tradicional de la monogamia en la mujer frente a la tolerada y casi normal poligamia del hombre machista Latinoamericano donde prima el lema "La mujer es de la casa y el hombre de la calle"

Claro, en Ecuador tienen sus maridos, sus hijos y acá tienen otra pareja y lo hacen porque ellas piensan que el marido nunca las ha valorado, nunca las ha respetado, que siempre les trataba mal, que en sus narices le corneaba, que no le importaba nada, que ahora ellas está libres y no están presionadas por el marido, ni los hijos, están lejos y quizá porque ellas se casaron muy jóvenes.(A.pg3.p10)

En una nueva situación. h emigración permite a las mujeres mayor libertad para salir al ámbito público ya que el hecho de emigrar supone una aventura totalmente contraria a estar en la casa y porque además del hecho de estar solas, en sus tiempos de ocio pueden salir sin necesidad de consentimiento de su esposo o padres.

Ellas dicen que nunca han podido disfrutar de la libertad porque se han casado de quince o dieciocho años y ahora que tienen la libertad lo quieren aprovechar al 
máximo y por eso a veces si tienen una pareja y no les va bien, entonces van en busca de otro y por eso ellas están como unas quinceañeras y yo las entiendo y digo quizá es que han sufrido mucho y ahora viven como adolescentes, se visten como adolescentes, más modernas, no se visten como señoras porque dicen que en Ecuador se vestían como señoras ya, que se dejaron ya de arreglarse o maquillarse porque el hecho de que tenían ya su marido, sus hijos o a veces el marido no les dejaba que estén al día con la moda pero en cambio como aquí están solas, ni nadie nos controla, ellas tratan de verse mejor, lucirse mejor.(A.pg4.p11)

A pesar de lo escaso que es el tiempo libre, el salir en sus días libres a pasear por las calles o reunirse con amigos, les ha obligado a ocupar la calle con la disponibilidad de un tiempo de ocio ha determinado la plasmación de espacios de encuentro como pueden ser puntos clave dentro del la ciudad o casas, sitios donde salen, se reúnen donde hacen llamadas telefónicas, envíos de cartas además que allí se divierten, bailan solas y les da la posibilidad de conocer a otros hombres. 


\section{CONCLUSIONES GENERALES.}

Las conclusiones son presentadas atendiendo al orden de los objetivos del estudio e integrando las conclusiones parciales encontradas en los apartados anteriores. En cuanto al supuesto que guío la investigación fue sostener que las mujeres que han debido migrar no sólo debieron atravesar un cambio de escenario geográfico, social y cultural sino que dicho cambio generó un cambio en el mundo de vida, en el estilo de vida, en las expectativas de ésta, en una nueva identidad social y cultural; experiencia atravezada por la identidad de género. Sin embargo, como se describe en los testimonios recogidos el proceso no es lineal, homogéneo e idéntico. Cada uno de los aspectos que intervienen en esta problemática corresponden a elementos de la experiencia para una mayor profundización del fenómeno.

Las implicaciones de esta tríada migración/identidad/género en un grupo de mujeres migrantes ecuatorianas, son analizadas en los resultados y conclusiones de este trabajo; así como algunos otros elementos no contemplados en los propósitos de esta investigación, ni en los supuestos que la guiaron; especialmente relacionado con el carácter socio-político de la migración femenina. Las conclusiones generales son presentadas a partir de cuatro apartados que engloban la problemática mencionada. El sexo, la edad, país de origen, escolaridad, estructura familiar son variables que caracterizan la migración; por lo tanto al tratar de caracterizarla a partir del cruce de las mismas y bajo una dimensión socio-cultural, socio-productiva y algunos aspectos sicológicos relacionados con la asimilación cultural, la identidad, la aculturación material, dan como resultado algunas conclusiones que se describen a continuación:

\subsection{Por qué migran las mujeres?}

Lo primero que habrá que preguntarse es ¿Porqué hay en las corrientes migratorias actuales una altísima presencia de mujeres? Una de las respuestas respecto de la motivación para viajar se encuentran entre el grado de desempleo por sexo, oportunidades económicas y factores socio-culturales en los países de origen; por tanto habría que suponer que esta 
condición se relaciona con un tipo de migración selectiva por edad relacionada con motivos educacionales y laborales en su mayor parte además un tipo de estructura familiar que facilita al inmigrante su traslado y la posibilidad de manejar un nivel de incertidumbre y de asumir mayores riesgos. Sin embargo, es necesario hacer notar que las personas (hombres o mujeres) al trasladarse solas lo hacen por voluntad propia aunque sean obligadas por las circunstancias, mientras que cuando es el grupo el que se traslada, en general es uno de los dos cónyuges quien decide el traslado y el otro lo asume de manera pasiva. Siendo estos aspectos claves en el proceso adaptativo.

Las familias funcionan como unidades de sustentación de los procesos migratorios: la forma, los motivos y las estrategias migratorias son influenciadas por el nivel de recursos del hogar, por la estructura, edad de la familia,etc. A su vez, diferencias de género en los papeles económicos y sociales atribuidos en la familia (rol y función) influyen en la decisión modifican la concepción de las estrategias domésticas e influencian la composición por sexo de la migración laboral. OEn este contexto, La mujer surge como sujeto activo en las diferentes etapas del proceso migratorio: en las estrategias para la obtención de su financiamiento, en la mantención de redes de apoyo, tanto en el punto de partida como en el punto de llegada, en el planeamiento de nuevas migraciones, en las estrategias de adaptación y de inserción en la fuerza de trabajo; por lo tanto, queda claro que la evidencia de gran parte de las empresas migratorias femeninas sobrepasan bastante el supuesto papel de "miembro dependiente de la familia”.

\section{2 ¿Qué características asume la migración femenina en el lugar de destino?}

En relación a este aspecto surge una interrogante ¿Porqué el desarrollo de una corriente migratoria pasa por la presencia de mujeres en el lugar de destino? La respuesta apunta a dos elementos de análisis muy importantes: Lo primero es que la masividad o el paulatino crecimiento de una corriente se relaciona con un tipo de migración laboral con características específicas como es el caso de muchos hombres y mujeres que han migrado sin sus familias; lo segundo es destacar el papel que cumplen las mujeres en este proceso ya que ella está en estrecha relación con procesos de habitualización e institucionalización de 
la experiencia, sobre la base de recetas y hábitos que han aprendido, tanto en un ámbito público como doméstico lo que implica un cierto manejo del medio social, cultural, productivo después de haber pasado una etapa de reconocimiento y de mayor riesgo y dificultad, en la que generalmente aparecen los hombres.

Evidentemente, las mujeres se relacionan de manera más directa con ciertos ritos de paso o la necesidad de dotar de “nuevos sentidos" bajo las llamadas estructuras transicionales de las que se habló en el abordaje teórico. Es de notar que a diferencia de otro tipo de colonias de inmigrantes como es el caso de peruanos y cubanos, el grupo de inmigrantes con las que se trabajó en esta investigación no mostró señales de estar participando en agrupaciones de carácter formal o de tener un específico lugar público de encuentro; más bien lo registrado fueron encuentros de carácter informal de tipo amistoso en las viviendas o lugares de habitación en torno a intereses en común como la comida, la música, formas de recreación y la necesidad de encuentros cercanos.

La conclusión en relación a esto, es que la mujer cumple un papel destacado en cuanto a generar "sentidos" a través de comentarios, consejos destacando recetas o habilidades para saber cómo enfrentar cada una de las etapas que se van viviendo.

Es de destacar además que cuando es el grupo familiar el que se traslada, pasa a ser un imperativo del grupo, la vinculación social con los distintos órdenes de la vida social del país que acoge por lo tanto su participación en comunidades de coterráneos no va a ser tan frecuente y hay mayor apertura a participar en grupos diversos; de todos modos el papel de la mujer sigue siendo fundamental en esta etapa en el ámbito doméstico ya que ella es la encargada de suministrar el " sentido de pertenencia" e "identidad" social a través de la recreación de pautas, hábitos, valores de su cultura.

Otro punto está en relación con la procedencia (rurales o urbanas o semiurbanas) y la participación en algún tipo de relación, encuentro, grupo como un sustituto indispensable en el aprendizaje y la sintonía en una nueva urbe y sus códigos. En algunos casos se evidencia mayor distancia entre el modo de vida anterior y en el que ahora se encuentran; 
específicamente en aquellos casos cuyo contexto era rural. Una explicación a este hecho parece estar muy relacionado con el manejo de distintas categorías de pensamiento (abstracción) y de relación en su comunicación recíproca tanto en un ámbito urbano como rural, tal como aparece en el trabajo de Munizaga. Es decir, el proceso de migrar a otro escenario geográfico no solo es un desafío de adaptación sino que se relaciona con un doble esfuerzo de reducción de complejidad empleando los términos de Arnold y Haefner. Por lo tanto, aquí se destaca principalmente el papel que juegan los distintos mecanismos de transición para las distintas segmentos de población que ha emigrado. Al incorporar este supuesto es necesario hacer una revisión respecto de las formas de vida anterior.

Los efectos de un cambio de forma de vida entre un ambiente y otro no siempre son alentadores y muchas veces son expresados en sus propias palabras como "costos sociales" que debieron asumir.

\subsection{La identidad}

Que sucede con la identidad de estas personas? Cada una de ellas ha sido creada y recreada social y culturalmente a través de procesos de habitualización e institución que son biográfica y socialmente reconocidos; Una vez que esta cotidianidad se rompe, se rompen también las pautas, las rutinas (sociales/naturales). Dicho quiebre a través del enorme esfuerzo implicado en la reconstrucción de marcos de referencia y de rutina, implican al parecer una ampliación del marco con el que uno realizó hasta ese entonces su experiencia social y cultural.

Las estrategias adaptativas vienen acompañadas de una carga cultural, ideológica, sicológica hacia la conformación de un nuevo ambiente, por lo tanto ni es fácil, lineal y homógeneo. Estas estrategias se relacionan con una cierta capacidad para discriminar y relacionarse con los distintos planos de la vida diaria, lo que implica haber adquirido un conocimiento y una destreza para con ellos y es una de las operaciones más complejamente adquiridas. Estos aspectos fueron recogidos con distinto tono y acento en cada una de las mujeres entrevistadas y fueron expresados como un conjunto de acciones tendientes a reducir la complejidad del nuevo ambiente. Se podría concluir que un buen proceso de 
descomplejización está relacionado con un normal nivel de expectativas, la capacidad para establecer contactos seguros y el grado de conocimiento del lugar a donde se arribará.

El tema de la identidad cultural no termina en una cierta capacidad adquirida para manejarse en los distintos planos de la vida sino que está relacionado con la trasculturalidad (fenómeno socio-antropológico). Ya que visto de esta manera supone pensarse culturalmente en términos de viaje en el que van apareciendo historicidades construidas, zonas disputadas en términos sicológicos, lugares de desplazamiento, interferencia e interacción.Se aprende a domesticar el ciclo, el cambio, el tránsito, el circuito y a partir de ahí en un larguísimo ir y venir se va construyendo la experiencia y la identidad.

La condición permanente en la que se encuentra el inmigrante es el vivir desarraigado, en términos de una historia dejada y heredada; Un cambio se produce al parecer lenta y forzosamente cuando la persona después de mucho tiempo asume que se está en una experiencia donde el pensamiento es errático y en tránsito, siempre cruzado por el recuerdo y se renuncia a la transparencia como fundamento vital. En apariencia se vive "morando" habitando en movimiento bajo una condición precaria donde se han desarmado los términos de referencia al romperse los límites del pensamiento basados en la experiencia común. Vivir en este contexto, supone entonces ir con la diferencia a cuestas pero ésta no funciona como barrera sino como signos de complejidad.

Lo que se reconoce como eje fundamental de relación social y cultural es una situación de encontrarse con el otro en términos de identidad. Se miran, se comunican, se intercambian y se mezclan pero no se desvanecen; sobre la base de una asimilación material que lucha por tomar un espacio en la afectividad y en el pensamiento. Estableciéndose claramente una estrecha relación entre hechos socio-antropológicos con otros sicológicos individuales.

\subsection{Identidad de Género y sus implicancias en el ámbito socio-político}

Uno de los aportes en esta línea quizá sea preguntarse ¿En qué medida los modelos prevalecientes, fuertemente marcados por el estereotipo de migrante masculino, dan cuenta 
de las diferencias introducidas por el género? Es decir, si los principios de organización de la vida social -clase, género, etnia- son fuerzas actuantes en todos los niveles de la vida social, y en qué medida se puede fomentar una articulación de los planos micro y macro en un modelo integrado. Se concluye que sería importante que se examinaran las políticas migratorias vigentes en la región desde la perspectiva de género, para evaluar las orientaciones estereotipadas sobre la condición masculina y femenina, que de un modo u otro terminan por generar prácticas discriminatorias contra la mujer, sin tomar en cuenta el significado de este proceso migratorio en cuanto a lo que van dejando detrás y el aporte que traen consigo al ser portadoras de un saber cultural.

Al develar parte de la especificidad de la migración femenina, se coloca en discusión el impacto de las políticas migratorias internacionales en el status de los migrantes tanto en los países de origen como en los receptores. Por ejemplo, se cuestiona hasta qué punto la implementación de ciertas políticas migratorias no habrá sido influenciada por imágenes estereotipadas de los papeles que hombres y mujeres (categorizados en variables) desempeñan en la sociedad de origen y en la de destino, imágenes que refuerzan la desigualdad de género y que terminan por agravarla. O más aún, ¿cómo pr oteger de la discriminación a los grupos más vulnerables dentro de las mujeres migrantes?

De esta forma, es sido posible formular recomendaciones en el sentido de que se adopten medidas que garanticen el acceso de las mujeres migrantes al mercado del trabajo, a la seguridad social y a una igualdad de oportunidades.En segundo lugar, esta bibliografía ha tenido también implicaciones teóricas: los estudios sobre la migración femenina sirven para criticar las teorías migratorias basadas en los modelos económicos clásicos, toda vez que los movimientos migratorios de mujeres no se explican fácilmente como producto de decisiones individuales orientadas por un comportamiento económicamente racional. Ellas son un eslabón de una cadena originada en países desarrollados o en vías de transformación, sin embargo, es una unidad social la que está actuando, una red familiar que se reacomoda a esta condición de circulación del trabajo femenino. La feminización de las migraciones, reflejarían un nuevo modo de distribución y utilización creciente de la fuerza de trabajo 
femenina, en particular, de las mujeres del tercer mundo. Su sentido último, por lo tanto, sería dado por la globalización de la economía.

En su mayor parte, la transferencia de mujeres a países desarrollados garantiza, a su vez, la existencia de una oferta de trabajo barata, principalmente en las grandes ciudades. Esta mano de obra se utiliza en el sector manufacturero degradado y terciario, en los servicios de bajo costo y también en ciertos servicios cuyo crecimiento está asociado a una distribución polarizada de la renta, como son los servicios personales y el servicio doméstico.

Para autores como Gregorio Gil (1999) y Boyd ( 1988), las alteraciones recientes en los flujos migratorios, y sus implicaciones macroeconómicas, también representan la "madurez de las corrientes migratorias estimuladas por las redes sociales basadas en lazos familiares/domésticos, de amistad y comunitarios. Ligando migrantes y no migrantes en una compleja malla de relaciones sociales e interpersonales, como es el caso de las abuelas o tías maternas que acuden al llamado de auxilio de las madres para la crianza y control de sus hijos, el caso de hijas que siguen a sus madres en el propósito de buscar mejores perspectivas de vida o por último el caso de gente que ve en este tránsito un modo de vida, favorecido por la ilegalidad, la confianza y el desconocimiento son parte del mismo engranaje. Dichas redes proveen información, asistencia social y financiera. Estas redes son también una forma de rito de paso o de tránsito ya que modelan los efectos de la migración - desde la no-migración, a la inmigración, a la migración de retorno y a la continuidad de los flujos migratorios.

El análisis de la bibliografía sugiere que es posible rescatar una cuestión básica ¿Qué es lo consustancial a los mecanismos de clase, genéro y lugar de origen en la conformación de procesos migratorios y en la inserción de los migrantes en la sociedad receptora? ya que el género, por sí solo, es insuficiente para especificar las condiciones de la mujer migrante, dentro o fuera de su país de origen. No bastan para explicar por qué la mujer migrante es la que responde al perfil asexuado del trabajador exigido en este nuevo momento de producción capitalista. 
A la hora de integrar todos los testimonios dentro de un mismo eje "género" éste se hace muy estrecho para explicar la influencia de otros factores como son la edad, el nivel educacional, el nivel socio-económico en los proceso migratorios; ya que dependiendo de las motivaciones para trasladarse más las condiciones de llegada al país el papel de la mujer (activo-pasivo) determina distintos modos de adapatación, asimilación e identidad social y cultural.

Al recuperar y destacar aquí una imagen activa de mujer en los procesos migratorios sobre la base de una perspectiva de género se rescata además una concepción más dinámica del grupo familiar, como estructura de relación entre géneros y entre generaciones, con conflictos, cuestionamientos de autoridad, reformulaciones, juegos de poder. Etc.

El desarrollo de una reflexión más profunda sobre género, familia y migración, se resiente tanto por la falta de análisis de datos agregados al nivel nacional como por la ausencia de estudios puntuales. Más aún estos estudios puntuales son de fundamental importancia para la detección del modo como las relaciones de género y las diferencias en los sistemas de género interfieren en los mecanismos migratorios y qué alteraciones ocurren en estas relaciones en los países receptores.

\section{REFERENCIAS BIBLIOGRÁFICAS}

IBAÑEZ, JESUS. 1997. “Teoría DE LA Conversación” en: El Regreso del Sujeto: La Investigación Social de Segundo Orden. Editorial Siglo XXI, Madrid

ALONSO,L.E. 1993. "Sujeto y Discurso: El lugar de la entrevista Abierta en las Prácticas de la Sociología Cualitativa" en: Métodos y Técnicas cualitativas de investigación en Ciencias Sociales. Coordinadores: Delgado, J.M. y Gutiérrez, J. Ed. Síntesis Psicología. España.

RUIZ OLABUÉNAGA, JOSÉ. I. 1996. Metodología de la Investigación Cualitativa, Universidad de Deusto, España 
BALAN, J. 1990. "La Economía Doméstica y las Diferencias entre los Sexos en las Migraciones Internacionales: Un Estudio sobre el Caso de los Bolivianos en Argentina". Estudios Migratorios Latinoamericanos, Prolade, Argentina.

BASTIDE, ROGER. 1973 El Prójimo y el Extraño. El Encuentro de las Civilizaciones Amorrortu, Buenos Aires.

BOGUE, DENIS. 1969. “Técnicas e Hipótesis para el Estudio de la Migración Selectiva” en: Notas sobre Experiencias con Migrantes en los Estados Unidos. Universidad de Chicago.

CHAMBERS, IAN. 1994. Migración, Cultura e Identidad, Amorrortu, Buenos Aires.

DE CERTEAU, MICHEL. 1988. The practice of everyday life, University of California Press.

GERMANI GINO. 1970. “Asimilación de Migrantes en el Medio Urbano” en: Sociología de la Modernización, Paidos, Buenos Aires

GREGORIO GIL, CARMEN. 1999. “¿Por qué Migran las Mujeres?”, Revista Perspectivas, \#13, Madrid,

GOODENOUGH,WARD. 1975. "Cultura, Lenguaje y Sociedad" en: El Concepto de Cultura: Textos Fundamentales, compilador: J.S.Kahn, Anagrama, Barcelona

HAEFNER,C; ARNOLD M. 1988. "La Aculturación Psicológica en Migrantes Forzados: El Caso Chileno" en: Actas del Primer Congreso Chileno de Antropología, Santiago

JOOPP, ALBERTS, 1978. "Hacia un mejor Entendimiento de los Motivos para Migrar" en: Notas de Población, Celade, Costa Rica 
KRISTEVA JULIA.1990. Stranieri a se Stessi, Feltrinelli, Milán

MARMORA, L. 1994. “Apertura o Restricción: lo Formal y lo Real en las Políticas Migratorias del Cono Sur" en:. Actas del Seminario Distribución y Movilidad Territorial de la Población y Desarrollo Human,o (Fundación Bariloche, CENEP, PROLAP). San Carlos de Bariloche.

MATTOS, CARLOS A. DE. 1994. “Capital, Población y Territorio en la América Austral. ¿Dispersión o Concentración?” en: Actas del Seminario Distribución y Movilidad Territorial de la Población y Desarrollo Humano, (Fundación Bariloche, CENEP, PROLAP), Argentina.

MUNIZAGA, CARLOS. 1978. "Estructuras transcicionales en la migración de los Araucanos de hoy a la ciudad de santiago de Chile" en: Revista de la facultad de Arquitectura de la U. de Chile.

SAID EDWARD.1990. "Reflections on Exile" en: Out there, Marginalization and Contemporary Cultures, Cambridge

SINGER,PAUL. 1972. "Migraciones Internas. Consideraciones teóricas sobre su Estudio” en Migración y Desarrollo. Flacso. Buenos Aires.

PELLEGRINO, A. 1989. Migración internacional de latinoamericanos en las Américas. Universidad Católica Andrés Bello/CELADE/Agencia Canadiense para el Desarrollo Internacional, Santiago de Chile

PROYECTO IMILA (CELADE, 1987) datos obtenidos por censos nacionales en la vuelta de 1980.

CELADE.1987. Boletín demográfico.. Santiago, Chile 